\title{
A magyar gazdasági növekedés térbeli korlátai - helyzetkép és alapvető dilemmák
}

„Ha meg szeretnénk érteni a nemzeti növekedé-
si ütemek különbségeit, jó azzal indítani, miért
különböznek a regionális növekedési ütemek."

(Krugman [2003] 17. o.)

A makrogazdasági kérdésekkel kiváló tanulmányok sora foglalkozik, míg a magyar gazdasági növekedés térbeli elemzése háttérbe szorult. A téma fontosságát indokolja, hogy a volt szocialista EU-tagállamok között Magyarország gazdasága növekedett a leglassabban 2004 és 2016 között. Tanulmányunkban áttekintjük, hogy a növekedéshez melyik megye, megyecsoport milyen mértékben járult hozzá 2000-től/2004-től 2016-ig. Egyik alapvető megfigyelésünk, hogy amíg 2007-ig a növekedést elsősorban Budapest és vonzáskörzete generálta, addig a föváros 2010-től már egyértelmüen visszafogta növekedési ütemét, egyre inkább lemaradva több volt szocialista EUtagállam fővárosától. Az adatokból egy térbeli paradoxon rajzolódik ki: annak ellenére, hogy a gazdasági növekedés alapvető tényezői - például a képzett munkaerő, a $\mathrm{K}+\mathrm{F}-\mathrm{a}$ föváros térségében koncentrálódnak, itt szinte stagnál a növekedés, és csökken a munkatermelékenység. Az a négy-öt megye élénkíti a gazdaságot, amelyben külföldi érdekeltségü feldolgozóipar müködik, míg a többi megye - azok is, ahol egyetemi központok vannak - a jelentős EU-források ellenére csak mérsékelten járul hozzá a kibocsátás fokozásához. Ha a gazdaságpolitika nem veszi figyelembe a gazdaság térbeli müködésének sajátosságait és az ezekhez kapcsolódó régióspecifikus szakpolitikai intézkedések szükségességét, akkor az ország gazdasági növekedése a lehetőségekhez képest továbbra is visszafogott és sérülékeny marad.

Journal of Economic Literature (JEL) kód: O18, O40, R11.

A gazdasági növekedés vizsgálata régóta a közgazdaság-tudomány egyik kiemelt kutatási témaköre. A növekedési irányzatok és modellek alapkérdéseivel, a volt szocialista országok, köztük a magyar gazdaság növekedésével, annak egyes részterületeivel (monetáris, fiskális, gazdaságpolitikai, termelékenységi, versenyképességi stb.

Lengyel Imre egyetemi tanár, Szegedi Tudományegyetem Gazdaságtudományi Kar. Varga Attila egyetemi tanár, Pécsi Tudományegyetem Közgazdaság-tudományi Kar. A kézirat első változata 2018. március 19-én érkezett szerkesztőségünkbe. 
kérdéseikkel) hazai kutatók kiváló írásainak sora foglalkozik (Bod [2016], Csaba [2014], Chikán-Czakó [2009], Erdős [2006], [2017], Halmai [2018], Halpern-Oblath [2014], Kornai [2016], [2017], Kónya [2011], [2017], Mellár [2001], Mihályi [2011], Muraközy [2008], Valentinyi [2002]). A tanulmányok többsége makroökonómiai alapállásból az országot egységes egésznek tekinti, ami sok szempontból elfogadható, de a növekedési tényezők (emberi erőforrások, természeti erőforrások, tőkeállomány, technológia és vállalkozói szellem stb.) egyenlőtlen térbeli eloszlása miatt a térségek fejlődésének megértése a nemzeti szintü növekedés megértésének egyik lényeges dimenziója. A gazdasági növekedés vizsgálatának hagyományos mutatója a bruttó hazai termék (GDP), amely egy ország esetében lényegében térségei bruttó hazai termékének összessége, így egy ország gazdasági növekedése visszavezethető térségei GDP-jének változására. Amint a mottónkban idézett Nobel-díjas Paul Krugman megjegyezte, a nemzetek növekedésének megértéséhez a kulcs a régiók növekedésének megértése.

A régiók mint szubnacionális térségek gazdasági növekedésével foglalkozó szakirodalom igen bőséges (Abreu [2014], Capello [2015], Capello-Nijkamp [2009], MaierTrippl [2009]). Cochrane-Poot [2014] kilenc mérvadó irányzatot sorol fel a hagyományos keynesi és neoklasszikus irányzatokkal együtt (262. o.). Az újabb megközelítések már további dimenziókat is beépítettek magyarázataikba, például a Romer-féle endogén növekedéselméletet, Lundvall innovációs rendszerekre vonatkozó elméletét, a Krugman-féle új gazdaságföldrajzot, az evolúciós gazdaságföldrajzot stb. (Acs-Sanders [2014], Elekes [2016], Varga [2009]). Ezeknél az irányzatoknál egyre inkább előtérbe kerül a földrajzi elhelyezkedés és a térbeli külső méretgazdaságosság, az úgynevezett agglomerációs előnyök (másképpen agglomerációs externáliák) szerepe (Capello [2015], Lengyel B.-Szanyi [2011], Lengyel I. [2010], Varga [2016]). A nagyvárosok gazdasági növekedése jóval erőteljesebb, mint a kisvárosoké vagy a rurális térségeké, főleg az emberi tőke koncentrálódása, a tudás térbeli túlcsordulása, a megosztható szolgáltatások méretgazdaságossága stb. következtében (Enyedi [2012]).

Tanulmányunkban a 2000 és 2016 közötti időszakban elemezzük azt, hogy melyik térség milyen mértékben járult hozzá az országos GDP növekedéséhez, javította vagy mérsékelte azt. Elemzéseink feltáró jellegủek, vizsgálataink során leíró módszertant követünk. Területi egységnek a megyéket vettük, ez a legkisebb olyan területi szint, ahol a GDP még jól becsülhető. A hasonló fejlődési pályán lévő megyékből típusokat képeztünk, ezáltal markánsabban megjelennek a jellemző térbeli folyamatok. A nemzeti számlák rendszere a közelmúltban megváltozott, a magyar megyék GDP-jét is a 2014ben bevezetett ESA2010 szerint újraszámolt adatokkal vesszük figyelembe. A megyékre folyó áras GDP-adatok állnak rendelkezésünkre, területi árindexek hiányában az országos volumenindexet használjuk mindegyik megyére a folyó áron közölt GDP-adatok 2010., illetve 2012. évi árakon történő átszámolásához. Tisztában vagyunk vele, hogy az egyes megyék gazdasági szerkezete és árszínvonal-változása az országos átlagtól eltérően alakulhat, de úgy véljük, hogy az így nyert adatok a főbb trendeket megfelelően érzékeltetik. ${ }^{1}$

\footnotetext{
${ }^{1}$ Magyarországon is gyüjtenek adatokat a fogyasztói árindex területi becslésére, havonta és megyénként, de ezen adatok köre szűk, és véleményünk szerint nem alkalmas a folyó áras megyei GDPadatok korrigálására. A területi árindex és a GDP számításának nehézségeiről lásd Dusek-Kiss [2008].
} 
Megjegyezzük, hogy az Eurostat területi árindexek hiányában a NUTS2 szintủ régiók folyó áras adataiból hasonló módon, az országos indexek segítségével számolja ki a régiók vásárlóerő-egységben közölt GDP-jét.

Elemzésünk alapvető kérdése: mely térségek és mikor erősítik, illetve gyengítik az ország gazdasági növekedését? Tanulmányunkban elöször az országos adatokat ismertetjük 2000 és 2016 között, összevetve a volt szocialista EU-tagállamok gazdasági növekedésével. Majd a megyék általunk definiált öt típusának gazdasági növekedését mutatjuk be, valamint azt, hogy ezek miként járultak hozzá az országos kibocsátáshoz, továbbá gazdasági növekedésük mennyiben vezethető vissza a munkatermelékenység vagy a foglalkoztatás javulására. Ezt követően a gazdasági növekedés föbb tényezői közül a munkaerő, a beruházások és a kutatás-fejlesztés fontosabb mutatóinak térbeli alakulását tekintjük át. Az adatokból kirajzolódó helyzetkép igen összetett, számos további megválaszolatlan kérdést vet fel, ezért tanulmányunk végén csak dilemmáinkat, átgondolandó javaslatainkat vázolhatjuk fel.

\section{Az ország és a megyék gazdasági növekedése}

Amint említettük, egy ország GDP-je térségeinek GDP-jéből tevődik össze, emiatt egy ország és térségeinek gazdasági növekedése összefügg. Mielőtt rátérünk a megyék gazdasági növekedésére, röviden áttekintjük a magyar gazdaságét, összevetve a többi kelet-közép-európai EU-tagállaméval.

Jól ismert, hogy Magyarország gazdasági növekedése 2000-2006 között dinamikus volt, az éves ütem 3,8 és 5,0 százalék között mozgott (1. táblázat). Ebben az időszakban a magyar gazdaság erőteljesen integrálódott az EU gazdaságába, főleg a külföldi működőtőke (továbbiakban: FDI) révén, továbbá az előcsatlakozási alapok és 2004től a felzárkózást segítő fejlesztési források is élénkítették a növekedését, hasonlóan a többi kilenc volt szocialista országéhoz (Csaba [2014], Farkas [2017], Gál és szerzőtársai [2016], Halmai [2014], Palánkai-Miklós [2014]). A magyar gazdaság esetében már 2007-ben megfigyelhető egy megtorpanás, míg a többi volt szocialista tagállamban a válság hatására 2008-ban vagy 2009-ben, egyetlen kivétel Lengyelország, ahol kisebb ingadozásokkal, de ütemesen folytatódott a növekedés.

A vizsgált intervallumon belül a magyar gazdaság éves növekedési ütemei alapján három időszakot különíthetünk el: a 2000-2006, a 2007-2012 és a 2013-2016 közötti periódusokat. A tíz országot tekintve a magyar gazdaság növekedése szinte mindig elmaradt a többitől: 2000-2006 között a 7., 2000-2010 között a 10. és 20002016 között a 9. helyen állt (ekkor Szlovénia került kevéssel mögénk). Ha 2004-hez képest, vagyis az EU-csatlakozás évéhez viszonyítunk, akkor Magyarország a 2012ig tartó periódusban a tíz ország közül az utolsó helyen állt, miként a 2016-ig tartó időszakban is. A volt szocialista országok között a csatlakozás óta a leglassabban a magyar gazdaság bővült, növekedési üteme alig haladta meg az EU28 átlagát. Ez a helyzet a 2012. évi mélypont óta változott, az utóbbi négy évben ismét élénkebb a magyar gazdaság növekedése, holtversenyben a 2-5. helyen található a kelet-középeurópai országok között. 


\section{1. táblázat}

A bruttó hazai termék (GDP) volumenének éves változása a volt szocialista EU-tagállomokban (ESA2010, százalék)

\begin{tabular}{|c|c|c|c|c|c|c|c|c|c|c|c|}
\hline 空 & $\stackrel{\infty}{\stackrel{\infty}{D}}$ & 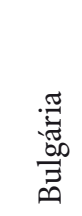 & 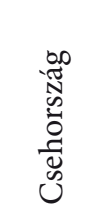 & 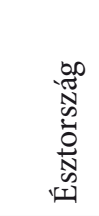 & 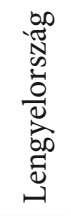 & 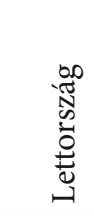 & 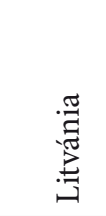 & 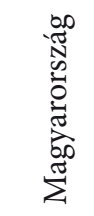 & 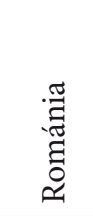 & $\begin{array}{l}\frac{\pi}{3} \\
\frac{\pi}{\pi} \\
\frac{0}{N} \\
N\end{array}$ & 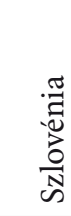 \\
\hline 2000 & 3,8 & 4,9 & 4,3 & 10,6 & 4,6 & 5,4 & 3,8 & 4,2 & 2,4 & 1,2 & 4,2 \\
\hline 2001 & 2,2 & 3,8 & 3,1 & 6,3 & 1,2 & 6,5 & 6,5 & 3,8 & 5,6 & 3,3 & 2,9 \\
\hline 2002 & 1,3 & 5,9 & 1,6 & 6,1 & 2,0 & 7,1 & 6,8 & 4,5 & 5,2 & 4,5 & 3,8 \\
\hline 2003 & 1,4 & 5,2 & 3,6 & 7,4 & 3,6 & 8,4 & 10,5 & 3,8 & 5,5 & 5,4 & 2,8 \\
\hline 2004 & 2,5 & 6,4 & 4,9 & 6,3 & 5,1 & 8,3 & 6,6 & 5,0 & 8,4 & 5,3 & 4,4 \\
\hline 2005 & 2,1 & 7,1 & 6,4 & 9,4 & 3,5 & 10,7 & 7,7 & 4,4 & 4,2 & 6,8 & 4,0 \\
\hline 2006 & 3,3 & 6,9 & 6,9 & 10,3 & 6,2 & 11,9 & 7,4 & 3,9 & 8,1 & 8,5 & 5,7 \\
\hline 2007 & 3,1 & 7,3 & 5,5 & 7,7 & 7,0 & 9,9 & 11,1 & 0,4 & 6,9 & 10,8 & 6,9 \\
\hline 2008 & 0,4 & 6,0 & 2,7 & $-5,4$ & 4,2 & $-3,6$ & 2,6 & 0,9 & 8,5 & 5,6 & 3,3 \\
\hline 2009 & $-4,4$ & $-3,6$ & $-4,8$ & $-14,7$ & 2,8 & $-14,3$ & $-14,8$ & $-6,6$ & $-7,1$ & $-5,4$ & $-7,8$ \\
\hline 2010 & 2,1 & 1,3 & 2,3 & 2,3 & 3,6 & $-3,8$ & 1,6 & 0,7 & $-0,8$ & 5,0 & 1,2 \\
\hline 2011 & 1,7 & 1,9 & 2,0 & 7,6 & 5,0 & 6,4 & 6,0 & 1,7 & 1,1 & 2,8 & 0,6 \\
\hline 2012 & $-0,5$ & 0,0 & $-0,8$ & 4,3 & 1,6 & 4,0 & 3,8 & $-1,6$ & 0,6 & 1,7 & $-2,7$ \\
\hline 2013 & 0,2 & 0,9 & $-0,5$ & 1,4 & 1,4 & 2,6 & 3,5 & 2,1 & 3,5 & 1,5 & $-1,1$ \\
\hline 2014 & 1,6 & 1,3 & 2,7 & 2,8 & 3,3 & 2,1 & 3,5 & 4,0 & 3,1 & 2,6 & 3,1 \\
\hline 2015 & 2,2 & 3,6 & 4,5 & 1,4 & 3,8 & 2,7 & 1,8 & 3,1 & 3,9 & 3,8 & 2,3 \\
\hline 2016 & 1,9 & 3,4 & 2,4 & 1,6 & 2,7 & 2,0 & 2,3 & 2,0 & 4,8 & 3,3 & 2,5 \\
\hline
\end{tabular}

$2000=100$ százalék

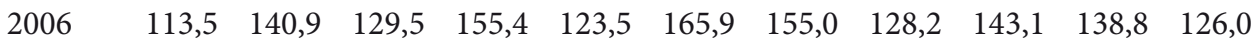

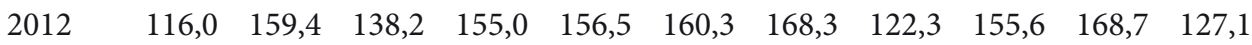

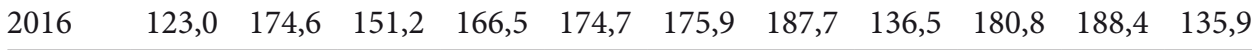

$2004=100$ százalék

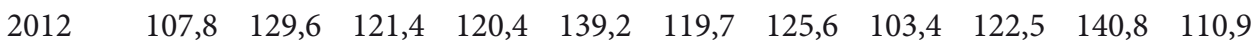

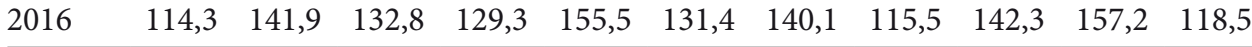

$2012=100$ százalék

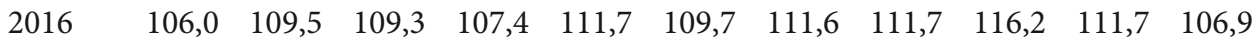

Forrás: KSH STADAT 7.3.4. tábla alapján a szerzők összeállítása. 
2. táblázat

A megyék egy lakosra jutó bruttó hazai terméke és változása, 2010. évi árakon

\begin{tabular}{|c|c|c|c|c|c|c|c|}
\hline \multirow[t]{2}{*}{ Megyék } & 2000 & 2006 & 2012 & 2016 & $2016 / 2000$ & $2016 / 2006$ & $2016 / 2012$ \\
\hline & \multicolumn{4}{|c|}{ ezer forint/fö } & \multicolumn{3}{|c|}{ százalék } \\
\hline Budapest & 4422 & 6215 & 5989 & 6311 & 143 & 102 & 105 \\
\hline $\begin{array}{l}\text { Győr-Moson- } \\
\text { Sopron }\end{array}$ & 2826 & 3248 & 3136 & 4225 & 150 & 130 & 135 \\
\hline Fejér & 2522 & 2752 & 2565 & 3259 & 129 & 118 & 127 \\
\hline $\begin{array}{l}\text { Komárom- } \\
\text { Esztergom }\end{array}$ & 1794 & 2942 & 2768 & 3244 & 181 & 110 & 117 \\
\hline Vas & 2405 & 2810 & 2575 & 3088 & 128 & 110 & 120 \\
\hline Pest & 1663 & 2424 & 2262 & 2499 & 150 & 103 & 110 \\
\hline Bács-Kiskun & 1558 & 1911 & 1927 & 2382 & 153 & 125 & 124 \\
\hline Zala & 1860 & 2318 & 2332 & 2364 & 127 & 102 & 101 \\
\hline Veszprém & 1836 & 2067 & 1957 & 2361 & 129 & 114 & 121 \\
\hline Csongrád & 1816 & 2122 & 2066 & 2348 & 129 & 111 & 114 \\
\hline Tolna & 1769 & 1892 & 2127 & 2306 & 130 & 122 & 108 \\
\hline Heves & 1551 & 1966 & 1801 & 2258 & 146 & 115 & 125 \\
\hline $\begin{array}{l}\text { Borsod-Abaúj- } \\
\text { Zemplén }\end{array}$ & 1399 & 1900 & 1697 & 2208 & 158 & 116 & 130 \\
\hline Hajdú-Bihar & 1606 & 2075 & 2065 & 2188 & 136 & 105 & 106 \\
\hline $\begin{array}{l}\text { Jász-Nagykun- } \\
\text { Szolnok }\end{array}$ & 1455 & 1853 & 1765 & 2042 & 140 & 110 & 116 \\
\hline Baranya & 1650 & 2032 & 1818 & 2027 & 123 & 100 & 112 \\
\hline Somogy & 1496 & 1778 & 1737 & 1926 & 129 & 108 & 111 \\
\hline Békés & 1498 & 1670 & 1580 & 1887 & 126 & 113 & 119 \\
\hline $\begin{array}{l}\text { Szabolcs-Szatmár- } \\
\text { Bereg }\end{array}$ & 1265 & 1531 & 1508 & 1767 & 140 & 115 & 117 \\
\hline Nógrád & 1217 & 1431 & 1210 & 1358 & 112 & 95 & 112 \\
\hline Ország & 2184 & 2839 & 2747 & 3124 & 143 & 110 & 114 \\
\hline
\end{tabular}

Megjegyzés: országos volumenindex alapján újraszámolva a megyék folyó áras adatait, a megyék sorrendje a 2016. évi érték szerinti rangsort mutatja.

Forrás: KSH STADAT 6.3.1.1., 6.1.1. és 3.1.1. tábla alapján a szerzők szerkesztése. 
Kérdésként vetődik fel, hogy az egyes időszakokban Magyarország gazdasági növekedését melyik térség milyen mértékben segítette elö. Melyik időszakban hol figyelhető meg dinamikus, és hol visszafogott növekedés? Elsősorban a közelmúltat, a 2012 utáni időszakot érdemes alaposabban vizsgálni, amiből következtethetünk a közeljövő gazdasági folyamataira is.

A 19 megye és Budapest egy lakosra jutó GDP-adatát tekintve, szembetünő a főváros kiemelkedő értéke és három dunántúli megye (Győr-Moson-Sopron, Fejér és Komárom-Esztergom) dinamizmusa (2. táblázat). Csak ez a négy térség haladja meg a vizsgált időszak nagyobb részében az országos átlagot, két megye (Vas és Pest) közel áll hozzá, míg a többi szinte együtt mozogva, jócskán elmarad tőle. Különösen Nógrád megye leszakadása látványos, 2006 és 2016 között 5 százalékos a visszaesése, a visegrádi országok megyéi között egyedüliként nem ért el fejlődést (Lengyel-Kotosz [2018]).

A 20 területi egység adatai nehezen áttekinthetők, ezért hasonló fejlödési pályáik alapján tipizáltuk a megyéket. Budapesten és vonzáskörzetében él a Közép-Magyarország régió lakosságának 86 százaléka, Pest megye lakosainak 67 százaléka (Tóth 2014), emiatt véleményünk szerint Budapest és Pest megye adatait - centrumként érdemes összevontan kezelni (ami egyértelmü például az „alvóvárosok”: Budaörs, Érd, Gödöllő esetében). A megyék többi típusát (lásd 3. táblázat) a 2000-től és 2012től megfigyelhető gazdasági növekedés, a 2016. évi fajlagos GDP-érték és gazdasági szerkezet alapján alakítottuk ki (Lengyel I. [2017] 410-411. o., Lengyel-Kotosz [2018], Lengyel I. és szerzötársai [2016] 634-635. o., Lux [2017]).

\section{3. táblázat}

Megyetípusok

\begin{tabular}{|c|c|c|}
\hline Megyetípus & Megye & $\begin{array}{c}\text { 2011. évi népszámlálás } \\
\text { szerinti lakónépességük } \\
\text { (ezer fö) }\end{array}$ \\
\hline Centrum & Budapest és Pest & 2971 \\
\hline $\begin{array}{l}\text { FDI } \\
\text { feldolgozóipari }\end{array}$ & $\begin{array}{l}\text { Győr-Moson-Sopron, Fejér, Komárom-Esztergom } \\
\text { és Vas }\end{array}$ & 1445 \\
\hline Újraiparosodó & $\begin{array}{l}\text { Bács-Kiskun, Zala, Veszprém, Heves, Borsod- } \\
\text { Abaúj-Zemplén és Jász-Nagykun-Szolnok }\end{array}$ & 2023 \\
\hline Tudásközpont & Baranya, Csongrád és Hajdú-Bihar & 1353 \\
\hline Rurális & $\begin{array}{l}\text { Tolna, Somogy, Békés, Szabolcs-Szatmár-Bereg } \\
\text { és Nógrád }\end{array}$ & 1668 \\
\hline
\end{tabular}

A 3. táblázatban szereplő megyetípusok elnevezése csak jelzésértékű, elemzésünkben ez másodlagos kérdés. Lakónépességük közel hasonló - a centrumot kivéve -, ami adataik összehasonlításakor előnyös. A típusok térbeli elhelyezkedésére jellemző, hogy például Észak-Dunántúlon találhatók azok a megyék, ahová áramlik a feldolgozóipari külföldi működőtőke (feldolgozóipari FDI), a szomszédságukban vagy Budapesthez közel, illetve a tradicionális ipartérségekben (például 
Borsod-Abaúj-Zemplénben) fekszenek az újraiparosodó megyék. A rurális megyék a déli, keleti országhatárnál helyezkednek el. Nógrád megye kissé kilóg ebből a sémából, bár az országhatárnál található, miként a 19 megyéből 14, de Budapesthez való földrajzi közelsége ellenére gazdasági teljesítménye igen gyenge.

A volt szocialista országok között a magyar gazdaság növekedése az egyik leglassabb az elmúlt másfél évtizedben, a 2004. évi EU-csatlakozás óta pedig a leglassabb, csak 2012-től érzékelhető némi élénkülés. Kérdés, hogy ezt a visszafogott országos növekedési ütemet melyik megyetípus és milyen időszakban erősítette vagy gyengítette.

\section{A megyetípusok gazdasági növekedésének jellemzői}

A megyetípusok egy lakosra jutó bruttó hazai termékének (GDP) alakulása alapján kirajzolódnak a térbeli folyamatok, és látható válik az országon belüli átrendeződés (1. ábra). A centrumban bár mindvégig magas az egy före jutó GDP - jócskán felülmúlva a többi térségtípusét -, de 2007 után lényegében stagnál. Erősen ingadoztak, viszont 2013-tól előre törtek azok a megyék, ahová a külföldi feldolgozóipari müködőtőke beáramlott. A másik három megyetípus jelentős mértékben leszakadt az országos átlagtól, mindvégig hasonló pályán mozogtak, az újraiparosodó megyék rosszabb pozícióból indulva már utolérték a tudásközpontokat. 2012 után mind az öt típusnál megfigyelhető bizonyos fellendülés, de eltérő dinamikával.

1. ábra

A megyetípusok egy lakosra jutó GDP-jének alakulása (ezer forint, 2010. évi árakon)

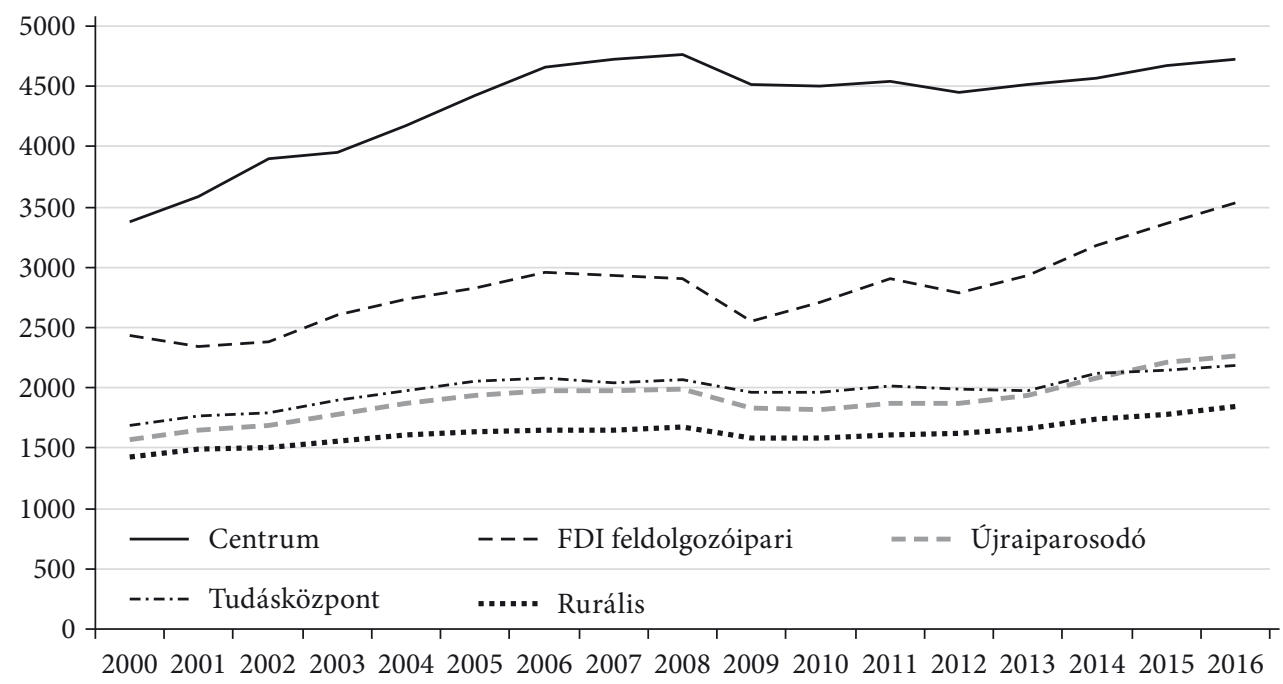

Forrás: KSH STADAT 6.3.1.1., 6.1.1. és 3.1.1. tábla alapján a szerzők szerkesztése.

Az országos éves növekedési ütemek alakulása alapján a megyetípusokra is ugyanazon három időszakot különítettük el: 2000-2006, 2007-2012 és 2013-2016 (4. 
4. táblázat

A megyetípusok egy lakosra jutó GDP-jének éves változása (százalék, 2010. évi árakon)

\begin{tabular}{|c|c|c|c|c|c|c|}
\hline & Centrum & $\begin{array}{c}\text { FDI } \\
\text { feldolgozóipari }\end{array}$ & Újraiparosodó & Tudásközpont & Rurális & Ország \\
\hline 2001 & 6,1 & $-3,7$ & 5,3 & 4,7 & 4,4 & 4,1 \\
\hline 2002 & 8,7 & 1,7 & 2,4 & 1,4 & 1,1 & 4,9 \\
\hline 2003 & 1,6 & 9,2 & 5,1 & 6,0 & 3,5 & 4,1 \\
\hline 2004 & 5,5 & 4,9 & 5,4 & 4,3 & 3,3 & 5,2 \\
\hline 2005 & 5,9 & 3,6 & 3,1 & 4,1 & 1,9 & 4,6 \\
\hline 2006 & 5,5 & 4,5 & 2,1 & 1,0 & 0,5 & 4,0 \\
\hline 2007 & 1,3 & $-0,8$ & 0,0 & $-1,9$ & 0,2 & 0,6 \\
\hline 2008 & 0,8 & $-1,1$ & 0,7 & 1,5 & 1,8 & 1,0 \\
\hline 2009 & $-5,2$ & $-12,2$ & $-7,9$ & $-5,1$ & $-6,0$ & $-6,4$ \\
\hline 2010 & $-0,3$ & 6,5 & $-0,4$ & $-0,2$ & 0,4 & 1,0 \\
\hline 2011 & 1,1 & 6,9 & 2,7 & 3,0 & 1,4 & 2,2 \\
\hline 2012 & $-2,1$ & $-3,8$ & 0,1 & $-1,2$ & 0,5 & $-1,4$ \\
\hline 2013 & 1,4 & 5,1 & 3,6 & $-1,0$ & 2,7 & 2,4 \\
\hline 2014 & 1,1 & 8,4 & 7,3 & 7,1 & 5,0 & 4,5 \\
\hline 2015 & 2,4 & 5,8 & 6,1 & 1,7 & 1,8 & 3,6 \\
\hline 2016 & 1,2 & 5,2 & 2,5 & 1,9 & 4,1 & 2,6 \\
\hline \multicolumn{7}{|c|}{$2000=100$ százalék } \\
\hline 2006 & 138,0 & 121,5 & 125,7 & 123,3 & 115,5 & 130,0 \\
\hline 2012 & 131,8 & 114,7 & 119,5 & 118,4 & 113,5 & 125,8 \\
\hline 2016 & 139,9 & 145,4 & 144,3 & 130,2 & 129,7 & 143,1 \\
\hline \multicolumn{7}{|c|}{$2004=100$ százalék } \\
\hline 2012 & 106,7 & 102,2 & 100,0 & 101,0 & 100,6 & 105,2 \\
\hline 2016 & 113,2 & 129,5 & 120,8 & 111,0 & 114,9 & 119,6 \\
\hline \multicolumn{7}{|c|}{$2012=100$ százalék } \\
\hline 2016 & 106,1 & 126,8 & 120,8 & 109,9 & 114,3 & 113,7 \\
\hline
\end{tabular}

Megjegyzés: az egy lakosra számolt GDP-növekedés üteme a megyetípusok lakónépességének változása miatt eltérhet az országos volumen növekedési ütemétől.

Forrás: KSH STADAT 6.3.1.1., 6.1.1. és 3.1.1. tábla alapján a szerzők számítása.

táblázat). A megyetípusok egy före jutó GDP-jének éves növekedési ütemei alapján érzékelhető, hogy a 2000-2006-os időszakban eltérő mértékben, de mindenhol növekedett a gazdaság, kiemelkedő mértékben, az országos átlag felett a centrumban (kivéve egy 2003-as megtorpanást). A 2007-2012 közötti visszaesés, stagnálás is mindenütt megfigyelhető, föleg a külföldi feldolgozóipari müködőtőkét befogadó és az újraiparosodó térségekben, igaz, hogy erőteljes ingadozások közepette. 2013-tól pedig újra mindenhol bővült a gazdaság, élénken elsősorban a külföldi 
feldolgozóipari működőtőkét befogadó és az újraiparosodó megyékben, míg a centrumban 2011-től jelentős elmaradás látható az országos átlagtól (itt a növekedés üteme az országos átlagnak csak körülbelül felét-harmadát éri el). A tudásközpontokban is minimális a növekedés, bár 2014-ben volt egy kiugrás, valószínüleg a nagy összegü EU-támogatások elszámolása miatt.

Az elmúlt több mint másfél évtizedben az országos növekedést (43,1 százalék) két térségtípus, a külföldi feldolgozóipari müködőtőkét befogadók (45,4 százalék) és az újraiparosodók (44,3 százalék) múlták felül, a centrumhoz tartozók (39,9 százalék) kissé, míg a tudásközpontok (30,2 százalék) és a rurálisak (29,7 százalék) jelentősen elmaradtak tőle. Ha az EU-csatlakozás évét (2004) tekintjük bázisévnek, akkor 2012-ig a centrumban figyelhető meg a legmagasabb növekedés (6,7 százalék), míg a többi térségben (a külföldi feldolgozóipari működőtőkét befogadó megyéket kivéve) szinte elenyésző. De 2016-ig a centrum előnye elolvadt, már a rurális térség is gyorsabban növekszik nála. A külföldi feldolgozóipari müködőtőkét befogadó és az újraiparosodó megyék 2004 után igen gyorsan, míg a tudásközpontok nagyon mérsékelten növekedtek. Ha a 2012-es évet vesszük bázisnak, akkor a centrum még a felét sem érte el a GDP országos gyarapodásának; hasonlóan visszafogott a tudásközpontok növekedése, nem éri el a rurális térségekét sem. Természetesen a centrum GDP-je abszolút mértékben növekedett 2012 után is, de mivel magas bázisról indult, ezért a növekedés alacsony ütemmel párosult.

$\mathrm{Az}$ adatok alapján a megyetípusok eltérö növekedési pályákat futottak be, föleg 2007 és 2012 után. Alapvető kérdésünk, hogy az országos GDP éves változásához melyik térségtípus mennyiben járult hozzá. Amint korábban megjegyeztük, föleg a 2012 utáni időszak térbeli folyamatai érdekesek számunkra.

Az országos GDP éves változásához a megyetípusok egy lakosra jutó hozzájárulása természetesen összefügg a 4. táblázatban bemutatott gazdasági növekedéssel (2. ábra). Mindvégig két térségtípus, a centrum és a külföldi feldolgozóipari müködőtőkét befogadó volt a domináns, még ha eltérő mértékben és különböző időszakban is. A három időszak jól elkülönül, 2002-2006 között és 2014-től mindegyik típus növelte az országos GDP-t (megjegyezzük, hogy a 2009. évi nagyarányú visszaesés is mindenütt hasonló mértékben figyelhető meg). 2001 és 2006 között kiemelkedett a centrum hozzájárulása a növekedéshez (az említett 2003-as év kivételével), de 2010-től már elenyésző mértékủ, $s$ a többi megyetípus hozzájárulása általában meghaladta a centrumét. A külföldi feldolgozóipari működőtőkét befogadó megyék kibocsátása erősen ingadozott, de 2013-tól határozottan növelik az országos GDP-t, miként az újraiparosodó megyék is. A tudásközpontok és a rurális térségek hozzájárulása az országos kibocsátás változásához mindvégig igen visszafogottan alakult.

Minek köszönhetö az egyes megyetípusok gazdasági növekedése 2012 után? A gazdasági növekedés közismert módon, dekompozícióval felbontható: az egy lakosra jutó GDP egyenlő a munkatermelékenység (LABOR PRODUCTIVITY, lp), a foglalkoztatási ráta (EMPLOYMENT RATE, er) és a munkaképes korúak arányának (ACTIVE POPUlATion, ap) szorzatával. ${ }^{2}$ Megjegyezzük, hogy a munkatermelékenység definíció

\footnotetext{
${ }^{2}$ Az egy lakosra jutó GDP megadható három tényező szorzataként (Dusek-Kotosz [2016], Lengyel I. [2010]): GDP/lakónépesség $=(\mathrm{GDP} /$ foglalkoztatottak $) \times($ foglalkoztatottak/munkaképes korúak $) \times$
} 
2. ábra

Az országos GDP éves változásához a megyetípusok egy lakosra jutó hozzájárulása (ezer forint, 2010. évi árakon)

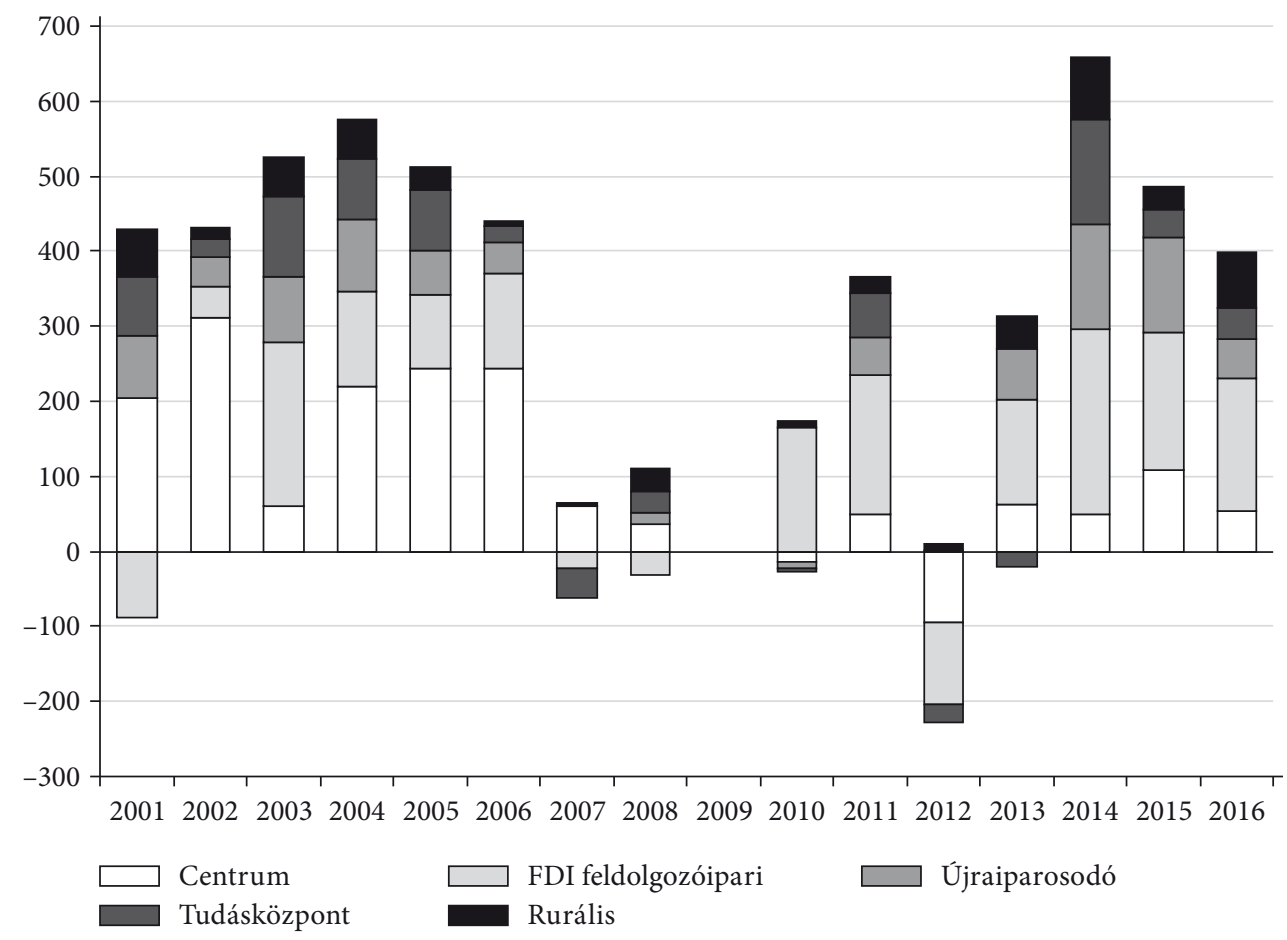

Megjegyzés: a 2009-es év adatait nem vettük figyelembe, mivel a nagy negatív értékek az ábra arányait erősen torzították.

Forrás: KSH STADAT 6.3.1.1., 6.1.1. és 3.1.1. tábla alapján a szerzők szerkesztése.

szerint az egy ledolgozott órára jutó kibocsátást jelenti, ezért itt mi csak egy közelítő számítást alkalmazunk. Elemzésünkben munkaképes korúnak a 15-64 éves korosztályt vettük, igazodva a hazai statisztikai adatszolgáltatási gyakorlathoz.

A 2012-2016 közötti növekedésben mindenhol a foglalkoztatás javulása volt a fö mozgatóerő, főleg a centrumban és az újraiparosodó megyékben (3. ábra). Az is megfigyelhetö, hogy a 15-64 éves munkaképes korúak számának alakulása mindenütt negatívan hatott a GDP bővülésére. Nagyobb eltérések a munkatermelékenység változásában figyelhetők meg, a külföldi feldolgozóipari müködőtőkét befogadó megyékben ennek a tényezőnek hasonló befolyása volt a növekedésre, mint a foglalkoztatás javulásának, az újraiparosodó térségben pedig mérsékelten fokozta a növekedést. A centrumban és a tudásközpontokban azonban erősen, a rurális térségekben kissé visszafogta a növekedést a munkatermelékenység változása.

$\times$ (munkaképes korúak/lakónépesség). A képlet röviden: $y=l p \times e r \times a p$. Két időszakot összevetve a reál-GDP-ben mért növekmény felbontható: $y_{1}-y_{0}=\left(l p_{1}-l p_{0}\right) \times e r_{0} \times a p_{0}+\left(e r_{1}-e r_{0}\right) \times l p_{1} \times a p_{0}+$ $+\left(a p_{1}-a p_{0}\right) \times l p_{1} \times e r_{1}$ 
3. ábra

A GDP egy lakosra jutó növekményének felbontása megyetípusonként 2012-2016 között (ezer forint, 2012. évi árakon)

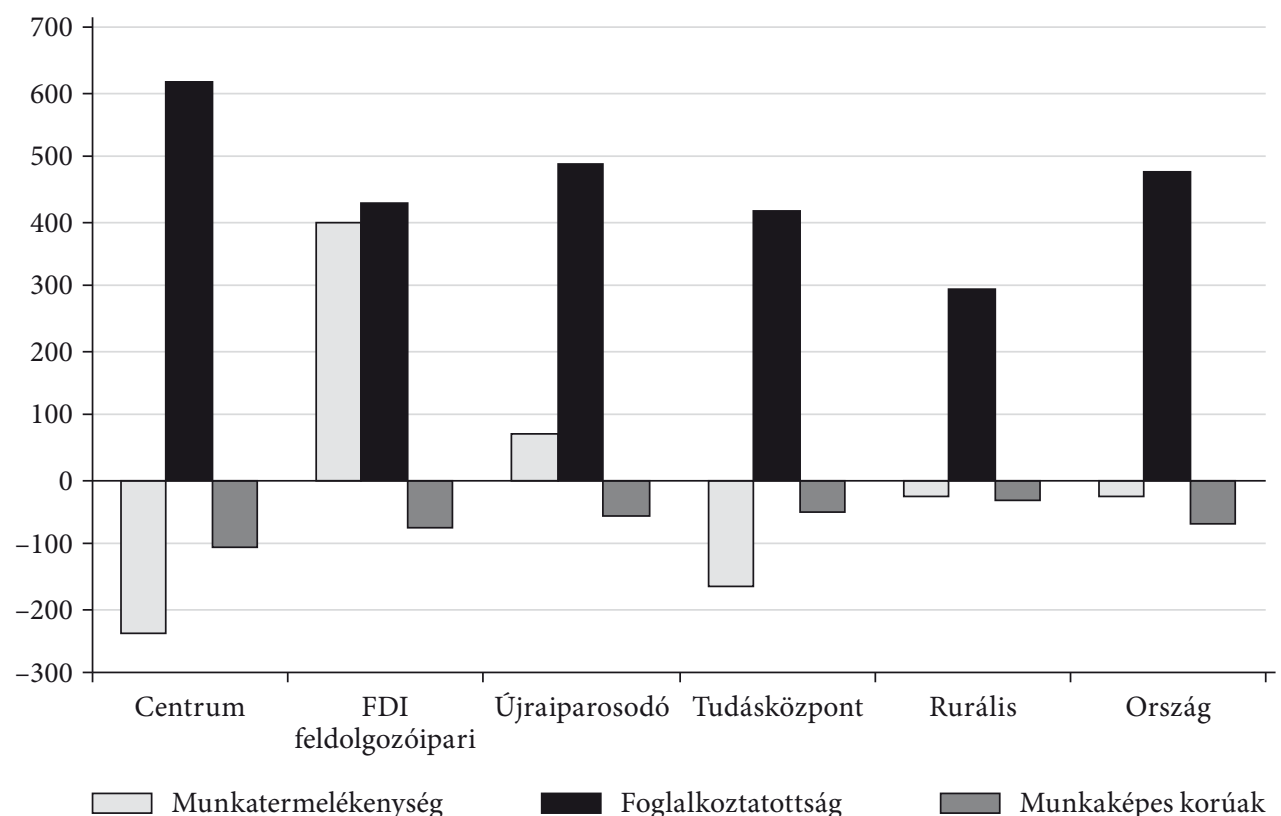

Megjegyzés: munkaképes korúak a 15-64 évesek.

Forrás: KSH STADAT 6.3.1.1., 6.1.1. és 6.2.1.2. tábla alapján a szerzők számítása.

Ha az egy foglalkoztatottra jutó GDP-vel becsüljük a munkatermelékenységet, akkor az adatsorokból látható, hogy 2000-től 2008-ig mindegyik térségben javult a munkatermelékenység, ezt követően viszont megváltoztak a területi folyamatok (4. ábra). Itt is szembetünő a centrum 2008-ig tartó gyors javulása, majd fokozatos hanyatlása, 2016-ban a 2005. évi szintre csúszott vissza. 2012-től csak a külföldi feldolgozóipari működőtőkét befogadó megyékben javult, az újraiparosodó térségekben stagnált, míg a tudásközpontokban és a rurális térségekben szintén csökkent a munkatermelékenység. Ez utóbbi két térségtípus munkatermelékenysége 2016-ban a 2000. évi szintre csúszott vissza, és másfél évtized alatt az újraiparosodó térségek utolérték a tudásközpontokat.

A fenti adatokból az derült ki, hogy a centrum, azaz Budapest és a tágan vett vonzáskörzetének tekintett Pest megye növekedése 2006-ig nagyon gyors volt, magas egy főre jutó GDP-t ért el, és javult a munkatermelékenység. Míg 2012-től a növekedés igen lassúvá vált, a föváros alig járult hozzá az ország gazdasági növekedéséhez, és csökkent a munkatermelékenység is.

Mennyiben tudható be ez a lelassulás a Williamson-hipotézis (más megközelítésben a Kuznets-görbe) érvényesülésének? Vagyis: érvényes-e Magyarországra az, hogy a felzárkózás kezdetén a nagyvárosok fejlődése gyors, megnőnek a területi különbségek, majd elérve egy magasabb fejlettségi szintet, a fejlett térségek növekedése lelassul, és területi kiegyenlítődés következik be (Capello [2015], Lengyel I. [2010])? 
4. ábra

Az egy foglalkoztatottra jutó GDP (ezer forint, 2010. évi árakon)

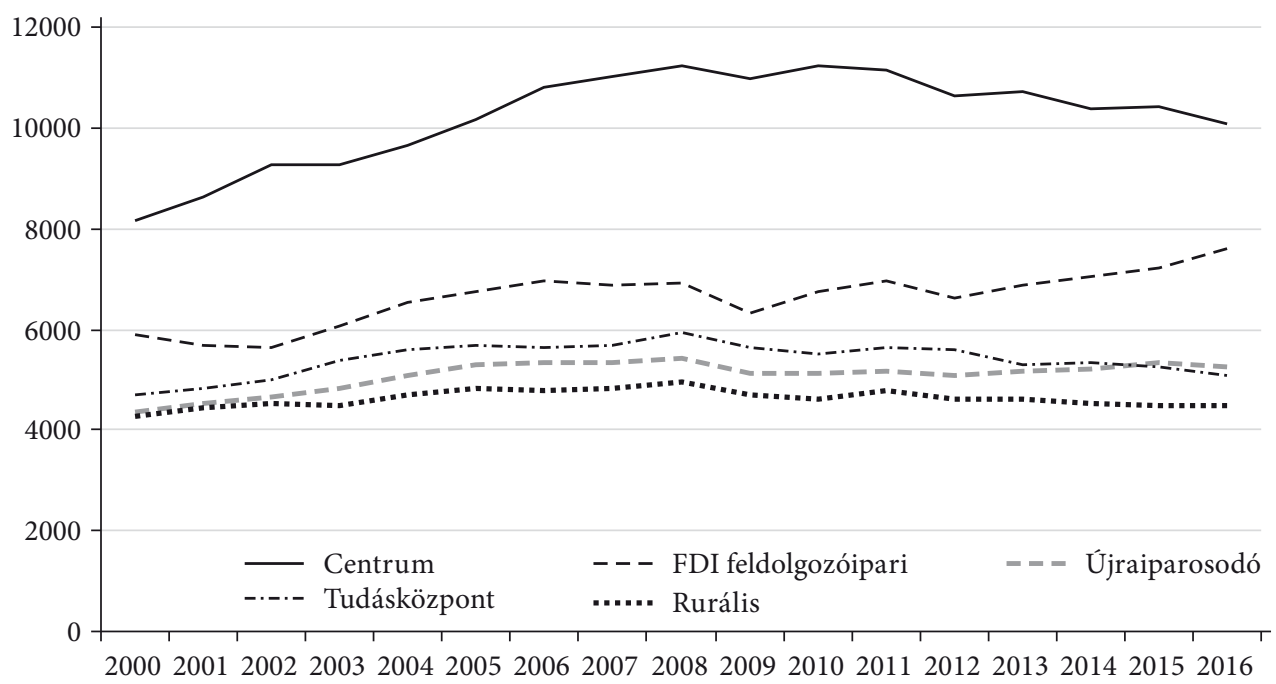

Forrás: KSH STADAT 6.3.1.1., 3.1.1. és 6.2.1.3. tábla alapján a szerzők számítása.

A kérdés megválaszolásához Budapest és a többi kelet-közép-európai volt szocialista ország NUTS3-as fóvárosi térségeinek egy före jutó GDP-jét hasonlítjuk össze (5. ábra). Ha vásárlóerő-paritáson vesszük a 2006-2015 között rendelkezésre álló adatokat, akkor elkülönül a fövárosok három csoportja. Az egyikbe Varsó, Pozsony és Prága tartozik, magas és dinamikusan növő értékkel (Prága a 2009. évi visszaesés után napjainkra magára talált). A másikba Bukarest, Budapest és talán Ljubljana (Közép-Szlovénia), míg a harmadikba a balti államok és Bulgária fóvárosai. Budapest még a középmezőnyben található, de egyre inkább leszakad a másik három visegrádi ország fövárosától, napjainkban már Bukarest is megelözi. A kép vegyes, van fejlett ország gyorsan növekedő és stagnáló fóvárossal is, így a Williamson-hipotézis nem dönthető el, de elgondolkodtató, hogy Budapest és térségének lassú fejlődése milyen tényezők hiányára vezethető vissza.

A statisztikai adatok és empirikus elemzések alapján föbb megállapításaink a következők.

a) Magyarország 2006-ig dinamikusan növekedett, amely folyamat már a globális válság előtt, 2007-ben megtorpant, és csak 2013-tól indult meg újra. A tíz volt szocialista országgal összevetve 2004-től, az EU-csatlakozástól számítva a legkisebb növekedést érte el.

b) 2006-ig mindegyik magyar megyében gyors gazdasági növekedés zajlott, a 2007-2012 közötti visszaesés is szinte mindenhol megfigyelhető, miként a 2013-tól újra élénkülő gazdaság is.

c) 2012-től mindegyik térségben elsősorban a foglalkoztatás javulása növeli a gazdasági kibocsátást, a munkaképes korúak számának csökkenése pedig mindenhol visszafogja, míg a munkatermelékenység javulása csak a külföldi feldolgozóipari müködőtőkét befogadó megyékben érezteti érdemben hatását. 


\section{5. ábra}

Az egy lakosra jutó GDP a volt szocialista országok NUTS3-as fóvárosi térségeiben vásárlóerő-paritáson (ezer PPS/fö)

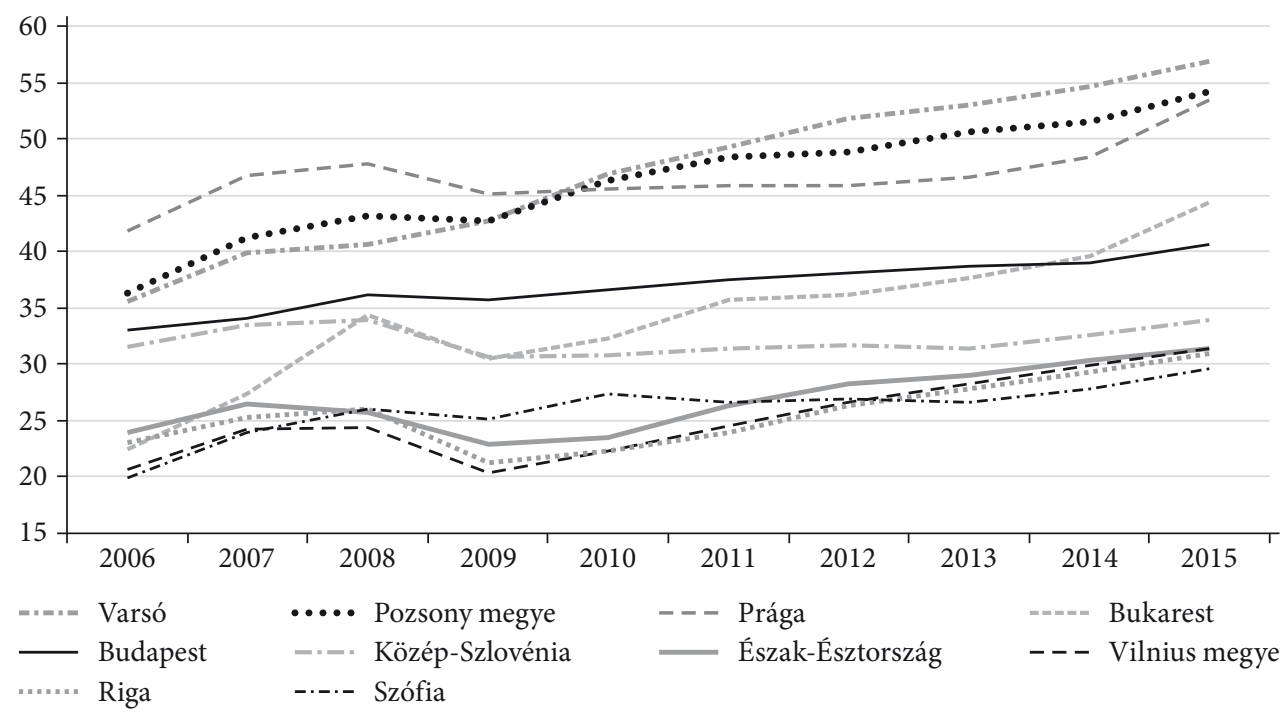

Forrás: EUROSTAT nama_10r_3gdp, nama_10r_3popgdp és tec0001 táblázatai alapján a szerzők számítása.

d) Budapest és vonzáskörzetének (Közép-Magyarország régió) egy főre jutó GDPje magas, 2006-ig húzta magával, de azóta visszafogja a hazai gazdasági növekedést. 2010-től a munkatermelékenység is visszaesett, és a főváros egyre inkább leszakad a visegrádi országok fóvárosaitól.

e) A vidéki „tudásközpontok” (Baranya, Hajdú-Bihar és Csongrád), ahol nagyobb közintézmények találhatók (például nagy létszámú egyetemek orvosi képzéssel és regionális klinikákkal, jelentősebb kutatóintézetek), szintén lassan fejlődnek, és viszszafogják az országos növekedést is.

f) 2013-tól elsősorban a külföldi feldolgozóipari működőtőkét befogadó megyék generálják az országos növekedést: Győr-Moson-Sopron, Fejér, Vas és Komárom-Esztergom. A kevésbé fejlett megyék közül több újraiparosodik (például Bács-Kiskun, Borsod-Abaúj-Zemplén), megfigyelhetően alacsonyabb szintről indul, de szintén dinamikus a növekedésük.

g) A rurális térségek növekedése is lassú, munkatermelékenységük a 2000. évi szintre esett vissza, pedig ezek az EU kohéziós politikájának fő kedvezményezettjei és a jelentős fejlesztési források célterületei.

A térségek növekedése több tényezőre vezethető vissza. Kérdés, hogy a térségtípusok eltérő növekedése melyik tényezőnek mennyiben tudható be. Vajon Budapesten a képzett munkaerő vagy a tőke hiányzik a válság utáni dinamikusabb növekedéshez? A hazai területi folyamatok áttekintését követően a növekedés alaptényezői közül az általunk fontosabbnak ítélt néhány mutató térbeli alakulását elemezzük. 


\section{A gazdasági növekedés alaptényezőinek térbelisége}

A szakirodalom alapján a gazdasági növekedés főbb tényezői: emberi erőforrások, természeti erőforrások, tőkeállomány, technológia és vállalkozói szellem. E tényezők mennyiségének és minőségének változása több mutatóval mérhető, jelen vitaanyagunkban csak néhány alapvetőt emelünk ki, amelyek véleményünk szerint jelzik a gazdasági növekedés hazai térbeli anomáliáit. Tisztában vagyunk vele, hogy a tényezők egy része csak hosszabb távon fejti ki hatását, de az egy-másfél évtizedes idősorok is fontos információkkal szolgálhatnak a folyamatok megértéséhez. Természetesen az általunk most nem vizsgált terület- és településfejlesztési politika és intézményrendszere is fontos szerepet tölt be a térségek fejlődésében (Pálné [2016], Rechnitzer-Smahó [2011]).

\section{Emberi erőforrások}

A munkaerö-állomány létszáma és alakulása mint mennyiségi mutató jelzi a munkakínálat változását (5. táblázat). A lakónépesség mint potenciális munkaerőforrás alakulása 2001 és 2016 között jelentős térbeli koncentrálódást mutat: országosan 403 ezer fővel, 3,9 százalékkal csökkent a lakosságszám, miközben a centrumban nőtt 169 ezer fővel. ${ }^{3}$ A többi megyetípusban mindenhol jelentős a csökkenés, legkevésbé a külföldi feldolgozóipari működőtőkét befogadó megyékben, míg a másik háromban 7-10 százalék közötti.

\section{5. táblázat}

A lakónépesség és a munkaképes korúak (15-64 évesek) száma és ennek változása megyetípusonként

\begin{tabular}{|c|c|c|c|c|c|c|c|c|}
\hline \multirow[t]{3}{*}{ Megyetípus } & \multicolumn{2}{|c|}{2001} & \multicolumn{2}{|c|}{2016} & \multicolumn{2}{|c|}{ 2016-2001 } & \multicolumn{2}{|c|}{$2016 / 2001$} \\
\hline & összes & $\begin{array}{l}15-64 \\
\text { évesek }\end{array}$ & összes & $\begin{array}{l}15-64 \\
\text { évesek }\end{array}$ & összes & $\begin{array}{l}15-64 \\
\text { évesek }\end{array}$ & összes & $\begin{array}{l}15-64 \\
\text { évesek }\end{array}$ \\
\hline & \multicolumn{6}{|c|}{ ezer fö } & \multicolumn{2}{|c|}{ százalék } \\
\hline Centrum & 2831 & 1961 & 3000 & 2006 & 169 & 45 & 106,0 & 102,3 \\
\hline $\begin{array}{l}\text { FDI } \\
\text { feldolgozóipari }\end{array}$ & 1449 & 1002 & 1424 & 970 & -24 & -32 & 98,3 & 96,8 \\
\hline Újraiparosodó & 2726 & 1838 & 2448 & 1647 & -278 & -191 & 89,8 & 89,6 \\
\hline Tudásközpont & 1392 & 951 & 1300 & 883 & -92 & -68 & 93,4 & 92,8 \\
\hline Rurális & 1803 & 1211 & 1626 & 1104 & -178 & -107 & 90,2 & 91,1 \\
\hline Ország összesen & 10200 & 6963 & 9798 & 6609 & -403 & -354 & 96,1 & 94,9 \\
\hline
\end{tabular}

Forrás: KSH STADAT 6.1.1. tábla alapján a szerzők számítása.

\footnotetext{
${ }^{3}$ Az egy före jutó GDP-t a lakónépesség számának növekedése csökkentheti, amennyiben a GDP elöállításában részt vevők köre kevésbé nő (például gyermekes családok odaköltözésekor), míg az elnéptelenedő térségekben növelheti.
} 
Munkaképesnek a 15-64 éveseket tekintve hasonló változások figyelhetők meg: egyedül a centrumban nőtt a számuk, míg máshol jelentősen csökkent. Érdekes, hogy a külföldi feldolgozóipari működőtőkét befogadó megyékben nagyobb mértékben csökkent a munkaképes korúak száma, mint az összes lakosságé. A centrumban koncentrálódott 2001-ben az ország munkaképes korú lakosságának 28,2 százaléka, s ez az arány 2016-ra 30,3 százalékra nőtt.

A munkaerő minősége is több mutatóval jellemezhető, az egyik legfontosabb az iskolai végzettség, elsősorban a felsőfokú végzettségüek arányának alakulása (6. táblázat). Hosszabb időszakot tekintve az utóbbi népszámlálások és a 2016. évi mikrocenzus adatai alapján az országban a rendszerváltástól 2016-ig 10,1 százalékról 22,8 százalékra nőtt a felsőfokú végzettségűek aránya. A centrumban 2016-ban a lakosság körülbelül harmada rendelkezett felsőfokú végzettséggel, míg a többi megyetípusban 15-21 százalékuk.

\section{6. táblázat}

A felsőfokú végzettségűek százalékaránya

\begin{tabular}{|c|c|c|c|c|c|c|c|c|}
\hline \multirow[t]{2}{*}{ Megyetípus } & \multicolumn{4}{|c|}{ Összes lakosságból } & \multicolumn{4}{|c|}{ 30-34 évesek között } \\
\hline & 1990 & 2001 & 2011 & 2016 & 1990 & 2001 & 2011 & 2016 \\
\hline Centrum & 15,5 & 19,4 & 28,4 & 34,3 & 19,3 & 22,0 & 39,3 & 47,2 \\
\hline FDI feldolgozóipari & 8,6 & 10,8 & 16,1 & 18,9 & 11,8 & 13,2 & 23,4 & 28,9 \\
\hline Újraiparosodó & 7,7 & 9,6 & 14,2 & 16,7 & 10,9 & 12,0 & 20,7 & 24,7 \\
\hline Tudásalapú & 8,9 & 11,4 & 17,4 & 21,0 & 11,9 & 14,8 & 26,7 & 31,7 \\
\hline Rurális & 6,9 & 8,5 & 13,1 & 15,2 & 10,2 & 10,6 & 19,6 & 23,2 \\
\hline Ország & 10,1 & 12,6 & 19,0 & 22,8 & 13,2 & 15,3 & 28,0 & 33,9 \\
\hline
\end{tabular}

Forrás: KSH 2016. évi mikrocenzus megyénkénti 1.2.3. táblája alapján a szerzők számítása.

Főleg a 30-34 éves korosztályra érdemes figyelni, a 2014-2020-as időszak európai uniós célkitűzései között szerepel, hogy a korosztály 40 százaléka szerezzen felsőfokú végzettséget. Magyarországon a 30-34 éves fiatalok között dinamikusan nőtt a diplomások aránya, 2016-ban már 33,9 százalékuk rendelkezett felsőfokú végzettséggel. Az országon belül jelentős különbségek figyelhetök meg, amíg a centrumban a fiatalok közel fele (47,2 százalék) diplomás, addig a rurális térségekben csak negyede (23,2 százalék). A hazai gazdasági növekedést generáló, külföldi feldolgozóipari működőtőkét befogadó és újraiparosodó megyékben is alacsony az arányuk, 28,9 és 24,7 százalék. A tudásközpontokban is csak 31,7 százalék, amely arányt az egyetemi és egészségügyi dolgozók jelentősen javítják, a versenyszférában valószínủleg itt is kevés diplomás dolgozik.

A felsőfokú végzettségűek aránya föleg a felsőoktatási intézményeknek helyet adó nagyvárosi térségekben magas, mivel a végzést követően a fiatalok többsége itt próbál elhelyezkedni, illetve a tudásintenzív cégek is szívesen müködnek ezekben. A nappali tagozatos hallgatók képzési hely szerinti ezer lakosra jutó számának alakulása is erős térbeli koncentrációt mutat: amíg 2016-ban a centrumban és a tudásközpontokban ezer lakosra 36,2 és 37,5 hallgató jutott, addig a rurális térségekben csak 2,9 hallgató, 
miközben 2005-ben még 7,9 (7. táblázat). De a gazdasági növekedést élénkítő külföldi feldolgozóipari müködőtőkét befogadó és az újraiparosodó megyékben is alacsony a fajlagos számuk, és rohamosan csökkent 2005 és 2016 között: 15,6 hallgatóról 8,3 hallgatóra, illetve 14,8 hallgatóról 8,1 hallgatóra.

\section{7. táblázat}

A felsőoktatásban nappali tagozatos hallgatók ezer lakosra jutó száma és megoszlása

\begin{tabular}{lrrrrrrrr}
\hline \multirow{2}{*}{ Megyetípus } & \multicolumn{3}{c}{ Hallgató/ezer lakos } & & \multicolumn{3}{c}{ Megoszlás (százalék) } \\
\cline { 2 - 3 } \cline { 7 - 8 } & 2005 & 2010 & 2016 & & 2005 & 2010 & 2016 \\
\hline Centrum & 34,8 & 37,8 & 36,2 & & 45,5 & 51,2 & 57,1 \\
FDI feldolgozóipari & 15,6 & 11,9 & 8,3 & & 10,4 & 7,9 & 6,2 \\
Újraiparosodó & 14,8 & 12,1 & 8,1 & & 14,4 & 11,2 & 8,3 \\
Tudásalapú & 36,4 & 42,1 & 37,5 & & 23,0 & 26,1 & 25,6 \\
Rurális & 7,9 & 4,7 & 2,9 & & 6,3 & 3,6 & 2,4 \\
Ország & 21,6 & 21,8 & 19,4 & & 100,0 & 100,0 & 100,0 \\
\hline
\end{tabular}

Forrás: KSH STADAT 6.2.5.5. tábla alapján a szerzők számítása.

A nappali tagozatos hallgatók száma országosan is csökkent, 2006-ban még 225 ezer fő volt, 2010-ben 218 ezer, majd évente 4-5 ezer fővel mérséklődve, 2016-ban már csak 190 ezer. Ez a csökkenés szinte csak három megyetípusban zajlott le, a külföldi feldolgozóipari működőtőkét befogadó, az újraiparosodó és a rurális megyékben, míg a centrumban és a tudásközpontokban minimális volt a változás. 2016-ban az utóbbi két típusban koncentrálódik a hallgatók 82,7 százaléka, ami előrevetíti, hogy a külföldi feldolgozóipari müködőtőkét befogadó és az újraiparosodó térségekben egyre nehezebb lesz kvalifikált, nemzetközileg versenyképes munkaerőt találni.

A munkaerő-állomány térbeli és időbeli alakulását néhány mutató alapján áttekintve érzékelhető, hogy az országban erőteljes koncentrációs folyamat zajlik. A centrumban nő a lakónépesség, köztük a munkaképes korúak száma, míg a többi térségtípusban csökken, ahol ezáltal szűkül a munkaerő kínálata. A diplomásokat tekintve is erős a koncentráció a centrumban, föleg a 30-34 évesek körében, míg a növekedést felmutató térségekben nemcsak a diplomások aránya alacsony, hanem rohamosan csökken a felsőoktatásban tanulók száma is. Természetesen a diplomások magas aránya a fővárosban (és a tudásközpontokban) részben megmagyarázható azzal, hogy itt találhatók az államigazgatás, a felsőfokú oktatás, az egyéb országos intézmények stb. székhelyei, részlegei is.

\section{Tőkeállomány}

A tőkeállomány fogalma szerteágazó, az anyagi létesítmények (például ingatlanok), gépek és berendezések, immateriális tőkejavak stb. széles körét fogja át. A tőkeállomány és egyes alkotóelemei is több mutatóval mérhetők, a térbeli folyamatok bemutatásához a beruházásokat, a külföldi közvetlen tőkebefektetéssel működő 
vállalkozások külföldi tőkéjét és az EU gazdaság- és vállalkozásfejlesztési forrásainak felhasználását tekintjük át. Úgy véljük, ez a néhány mutató is képes érzékeltetni a tőkeállomány térbeli alakulásának főbb vonásait.

A 2000 utáni egy lakosra jutó, megvalósulás helye szerinti, megyetípusonkénti beruházások alakulása érzékelhetően a növekedési ütemekkel összhangban változik (6. ábra). A centrum 2008-ig elöl szerepelt, majd látványosan visszaesett 2012-ig, és csak 2015-ben érte el újra a 2000. évi szintet. A külföldi feldolgozóipari működőtőkét befogadó térségekben erős ingadozás figyelhető meg, 2006-ban megtorpant a növekedés, és csak 2012-ben érte el és tartja a korábbi szintet. Az újraiparosodó megyék 2002-től az élen járnak, és 2014-2015-ben kimagasló értéket értek el (valószínüleg az autópálya-építések miatt is). A másik két megyetípus együtt mozgott, szembetünő, hogy 2013-tól a tudásközpontok egyre inkább hátrasorolódnak. Az is feltűnő, hogy a beruházások 2016-ban mindenütt és hasonló mértékben visszaestek, valószínüleg az EU-források kimerülése miatt. Természetesen a beruházások hosszabb időszakban fejtik ki hatásukat a gazdasági növekedésre, de ez a közel másfél évtizedes időszak is jelzi a megyetípusok közötti tartós eltéréseket és a centrum visszaesését.

\section{6. ábra}

Az egy lakosra jutó beruházások értékének alakulása (ezer forint, 2000. évi árakon)

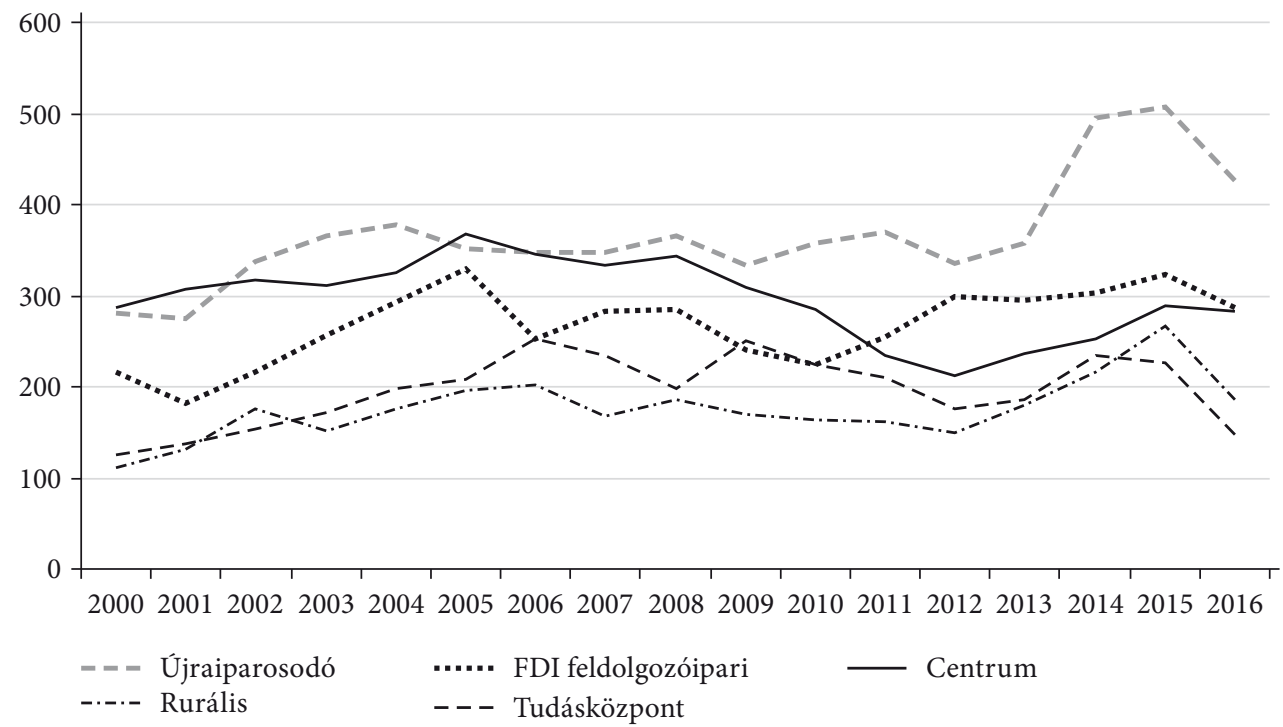

Megjegyzés: a KSH a teljes körüen megfigyelt vállalkozási kör, költségvetési és nonprofit szervezetek adott megye területén megvalósult beruházásainak adatait közli, függetlenül a beruházó területi elhelyezkedésétől; a többi szervezet beruházási teljesítményét székhely szerint veszi számba.

Forrás: KSH STADAT 6.3.3.1., 6.1.1. és 3.3.1. tábla alapján a szerzők számítása.

A külföldi müködőtőke (FDI) szerepe a magyar gazdaságban kiemelkedő, a külföldi irányítású leányvállalatok bruttó hozzáadott értékből való részesedése a második legnagyobb az EU-n belül, Írország után (2014-ben mindkét országban 53 százalék volt), 
az EU28 átlaga 24 százalék (KSH [2017]). A megyetípusokat tekintve, a centrumban koncentrálódik a külföldi müködőtőke, ami főleg az országos hatáskörü kereskedelmi bankok, biztosítók, nagykereskedelmi cégek, médiavállalkozások stb. tömörülésének tudható be (7. ábra). Ugyanakkor a centrumban 2009 és 2014 között minimálisan növekedtek a közvetlen külföldi befektetések (folyó áron), és 2015-ben visszaesést is lehetett tapasztalni. A külföldi feldolgozóipari működőtőkét befogadó térségek 2010től dinamikusan növekedtek (megjegyezzük, részben emiatt kapta elnevezését ez a típus), a folyamat 2015-ben kissé lelassult. A másik három megyetípusnál a külföldi működőtőke szerepe igen mérsékelt.

\section{7. ábra}

A külföldi közvetlen tőkebefektetéssel müködő vállalkozások egy lakosra jutó külföldi tőkéje (ezer forint, folyó áron)

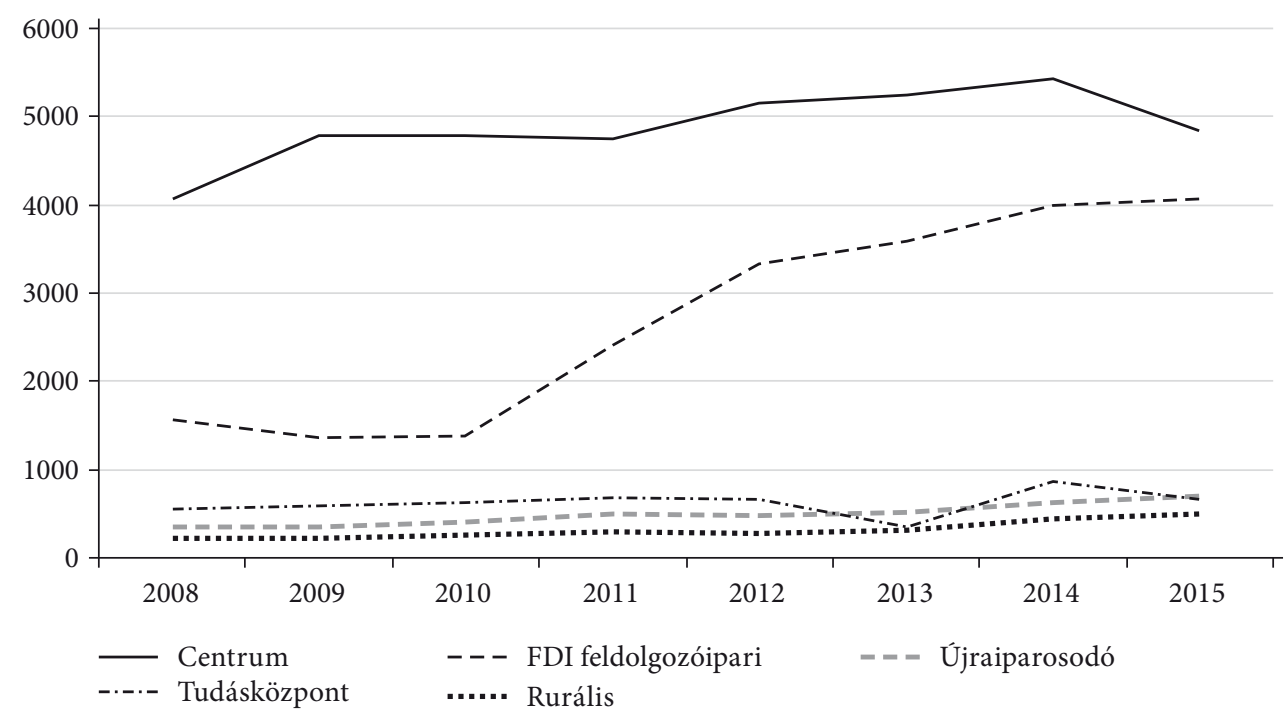

Forrás: KSH STADAT 6.3.2.5.2. és 6.1.1. tábla alapján a szerzők számítása.

Az EU-forrásokat és felhasználásukat tervezési időszakonként állapítják meg, a különböző időszakok terveiben mindig szerepelt olyan operatív program (OP), amelynek fö célja a közvetlen gazdaság- és vállalkozásfejlesztés, és kedvezményezettjei a vállalkozások voltak (KPMG [2017]). A 2004-2006-os időszakban a Nemzeti Fejlesztési Terv keretében a Gazdasági Versenyképességi OP (NFT-GVOP), a 2007-2013-as időszakban először az Új Magyarország Fejlesztési Terven belül a Gazdaságfejlesztési OP (ÚMFT-GOP), majd 2011-től az Új Széchenyi Tervben a Vállalkozásfejlesztési OP (ÚSZT-VOP) szerepelt (a három OP forrásaiból 2007-2016 között körülbelül 2000 milliárd forintot fizettek ki).

Az európai uniós gazdaság- és vállalkozásfejlesztési források egy lakosra jutó, kifizetett összegeit a projekt helyszíne alapján csoportosítva sajátos kép bontakozik ki (8. ábra). Az NFT-GVOP felhasználásában (csak hároméves időszak volt) az újraiparosodó térségek és a tudásközpontok jártak élen, az ÚMFT-GOP felhasználásában 
a centrum és a tudásközpontok, míg az ÚSZT-VOP felhasználásában egyértelmủen a centrum élvezett előnyöket, pedig a Közép-Magyarország régió fejlettsége miatt az ott müködő vállalatok lényegében már nem kaphattak volna támogatásokat. ${ }^{4} \mathrm{Az}$ adatokból kiderül, hogy a vállalati pályázatoknál a kevésbé fejlett térségek cégei háttérbe szorultak, holott ezeket a felzárkózási forrásokat főleg nekik szánták.

\section{8. ábra}

Az európai uniós gazdaság- és vállalkozásfejlesztési források egy lakosra jutó, kifizetett értéke (2004-2015) a projekt helyszíne alapján (ezer forint, folyó áron)

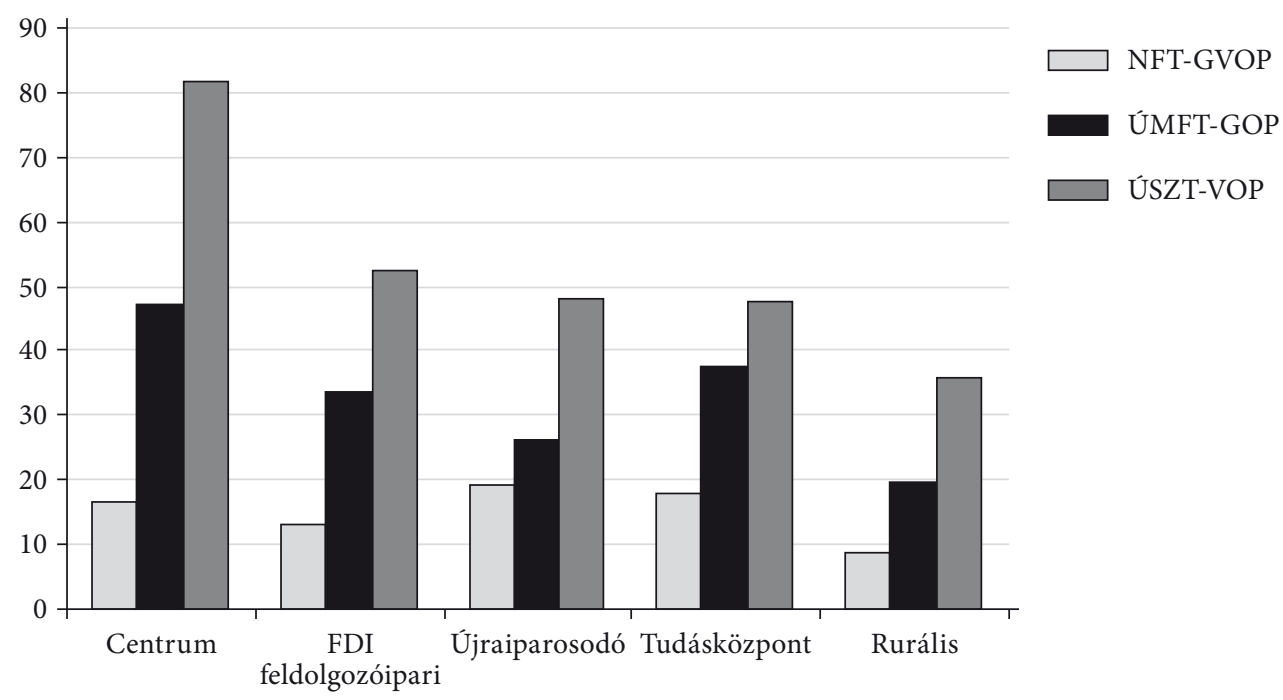

Megjegyzés: NFT-GVOP: Nemzeti Fejlesztési Terv Gazdasági Versenyképességi Operatív Program (2004-2006), ÚMFT-GOP: Uj Magyarország Fejlesztési Terv Gazdaságfejlesztési Operatív Program (2007-2013), ÚSZT-VOP: Új Széchenyi Terv Vállalkozásfejlesztési Operatív Program (2011-2013).

Forrás: EMIR alapján a szerzők szerkesztése.

A tőkeállomány néhány fontos adatának térségtípusonkénti eloszlásából és alakulásából érzékelhetö kapcsolatuk a gazdasági növekedéssel. A beruházások és a külföldi működőtőke alakulása az adatok alapján összhangban áll a gazdaság növekedésével, kivált erős kapcsolat látszik a külföldi müködőtőkét befogadó feldolgozóipari megyékben. A centrum vállalkozásainak juttatott uniós gazdaság- és vállalkozásfejlesztési források gazdaságélénkítő hatása viszont nem érzékelhető a gazdasági növekedésben. Ebben szerepet játszhat, hogy a támogatások odaítélésénél csak az adott vállalat adatait nézték, azt nem, hogy fellép-e térségi kiszorító hatás, azaz hány olyan cég megy tönkre, amelyek nem nyertek el forrásokat.

${ }^{4}$ Az európai uniós támogatási arány a régió fejlettségétől függött. Budapesten 2007-2010 között a nagyvállalatok a beruházás 25 százalékát, 2011 és 2013 között 10 százalékát kaphatták támogatásként, Pest megyében és a Nyugat-Dunántúlon mindkét időszakban 30 százalék volt a támogatási arány, a Közép-Dunántúlon 40 százalék, míg a többi négy régióban 50 százalék. [Forrás: Európai Bizottság B(2006) 4009 végleges.] 


\section{Kutatás-fejlesztés és szabadalmak}

A technológia és vállalkozói szellem mint növekedési tényező az előzőkhöz képest is jóval összetettebb, magában foglalja többek között a tudományos és müszaki ismeretek színvonalát, az újítások és szabadalmak hozamát, a vezetési ismereteket stb. (Török és szerzőtársai [2005]). E tényezőcsoportból a kutatás-fejlesztési ráfordításokat, a kutatók és a tudományos fokozattal rendelkezők számát, a szabadalmak térbeli alakulását tekintjük át, nem térünk ki többek között a vállalkozói készség és a vállalati növekedés regionális eltéréseire sem, amit Komlósi és szerzőtársai (2014), illetve Szerb és szerzőtársai (2017) részletesen elemeztek, avagy az innovációs rendszerek térbeliségére (Lengyel-Leydesdorff [2008]).

A kutató-fejlesztő helyek ráfordításai a $\mathrm{K}+\mathrm{F}$-költségböl és -beruházásból állnak

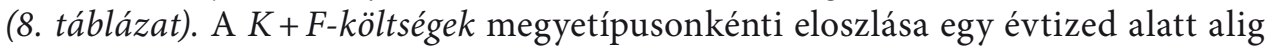
változott, stabilnak tünik, a centrumban és a tudásközpontokban koncentrálódik (együtt körülbelül 82-83 százalék). A $K+F$-beruházások már kissé erősebben ingadoznak, de továbbra is a centrumban és a tudásközpontokban koncentrálódnak (87 százalékról 73 százalékra csökkentek), de már az újraiparosodó megyékben is megfigyelhető a növekedésük (Miskolc, Veszprém, Kecskemét térségében). Természetesen az adatok az MTA és egyéb kutatóintézetek, egyetemi mühelyek térbeli eloszlásával állnak összefüggésben, föleg a költségeket tekintve.

\section{8. táblázat}

Az egy lakosra jutó $\mathrm{K}+\mathrm{F}-\mathrm{költség}$ és -beruházás értéke (ezer forint, folyó áron) és megoszlása (százalék)

\begin{tabular}{|c|c|c|c|c|c|c|c|c|}
\hline \multirow[t]{3}{*}{ Megyetípus } & \multicolumn{4}{|c|}{$\mathrm{K}+\mathrm{F}$-költség } & \multicolumn{4}{|c|}{ K+F-beruházás } \\
\hline & \multicolumn{2}{|c|}{$2005-2006$} & \multicolumn{2}{|c|}{$2015-2016$} & \multicolumn{2}{|c|}{$2005-2006$} & \multicolumn{2}{|c|}{$2015-2016$} \\
\hline & $\begin{array}{c}\text { ezer } \\
\text { forint/fö }\end{array}$ & százalék & $\begin{array}{c}\text { ezer } \\
\text { forint/fö }\end{array}$ & százalék & $\begin{array}{c}\text { ezer } \\
\text { forint/fó }\end{array}$ & százalék & $\begin{array}{c}\text { ezer } \\
\text { forint/fö }\end{array}$ & százalék \\
\hline Centrum & 43,2 & 68,5 & 88,8 & 68,6 & 9,8 & 75,2 & 9,6 & 52,7 \\
\hline FDI feldolgozóipari & 8,0 & 6,5 & 20,8 & 7,7 & 1,0 & 3,8 & 3,6 & 9,6 \\
\hline Újraiparosodó & 5,6 & 8,3 & 14,0 & 8,9 & 1,1 & 7,7 & 3,3 & 14,7 \\
\hline Tudásközpont & 19,0 & 14,5 & 38,7 & 13,0 & 3,1 & 11,6 & 8,2 & 19,8 \\
\hline Rurális & 2,2 & 2,1 & 4,4 & 1,9 & 0,4 & 1,7 & 1,1 & 3,3 \\
\hline Ország & 17,8 & 100,0 & 39,5 & 100,0 & 3,7 & 100,0 & 5,5 & 100,0 \\
\hline
\end{tabular}

Forrás: KSH STADAT 6.3.4.1. és 6.1.1. tábla alapján a szerzők számítása.

A kutatók és fejlesztők is a centrumban és a tudásközpontokban találhatók, míg a másik három megyetípusban alig dolgoznak (9. táblázat). A koncentrációs folyamat erősödik, amíg 2006-ban az ország kutatóinak 65,3 százaléka dolgozott a centrumban, addig 2016-ban már 69,4 százaléka. Térben hasonlóan koncentrálódnak a tudományos fokozattal rendelkező kutatók ( $\mathrm{PhD}$, kandidátus, MTA-doktor) is, körülbelül 80-83 százalékuk a centrumban és a tudásközpontokban dolgozik, amely térségekben 
pedig a gazdasági növekedés üteme minimális. Miközben a külföldi feldolgozóipari müködőtőkét befogadó és az újraiparosodó térségekben alig vannak kutatók, az országos átlag felét sem éri el a százezer lakosra jutó számuk.

\section{9. táblázat}

A kutatók, fejlesztők és tudományos fokozatúak százezer lakosra jutó száma és megoszlása

\begin{tabular}{|c|c|c|c|c|c|c|c|c|}
\hline \multirow[t]{3}{*}{ Megyetípus } & \multicolumn{4}{|c|}{ Kutatók $^{*}$} & \multicolumn{4}{|c|}{ Tudományos fokozatúak ${ }^{\star *}$} \\
\hline & \multicolumn{2}{|c|}{2006} & \multicolumn{2}{|c|}{2016} & \multicolumn{2}{|c|}{2006} & \multicolumn{2}{|c|}{2016} \\
\hline & fö & százalék & fö & százalék & fö & százalék & fö & százalék \\
\hline Centrum & 401 & 65,3 & 597 & 69,4 & 256 & 57,4 & 322 & 58,1 \\
\hline $\begin{array}{l}\text { FDI } \\
\text { feldolgozóipari }\end{array}$ & 91 & 7,5 & 124 & 6,9 & 57 & 6,5 & 74 & 6,4 \\
\hline Újraiparosodó & 61 & 9,2 & 96 & 9,1 & 48 & 9,5 & 56 & 8,3 \\
\hline Tudásközpont & 195 & 15,2 & 253 & 12,7 & 210 & 22,6 & 318 & 24,8 \\
\hline Rurális & 28 & 2,8 & 30 & 1,9 & 26 & 3,5 & 25 & 2,5 \\
\hline Ország & 174 & 100,0 & 263 & 100,0 & 126 & 100,0 & 170 & 100,0 \\
\hline
\end{tabular}

* A kutató-fejlesztő helyek K+F-számított létszámából a kutatók és fejlesztők, ${ }^{* *}$ MTA-tagok, MTA-doktorok, PhD (és kandidátusok).

Forrás: KSH STADAT 6.3.4.1. és Területi statisztikai évkönyvek 4.3.1. táblái alapján a szerzők számítása.

Megjegyezzük, hogy az államilag támogatott doktori (PhD-) képzésre felvehető keretszám is erősen koncentrálódik, természetesen a minőségi egyetemi tudományos kapacitáshoz igazodva. Például 2018-ban a centrumnak jut az országos férőhelyek 54 százaléka, a tudásközpontoknak 35 százaléka, így a gazdasági növekedésben élen járó térségekben minimális a keretszám, például a külföldi feldolgozóipari működötőkét befogadó megyékben csak 4 százalék (https://doktori.hu).

Az Európai Szabadalmi Hivatalnál bejegyzett, benyújtott szabadalmak térbeli eloszlása is nagyon egyenlőtlen, 2004 és 2012 között a centrumban és a tudásközpontokban található a 85-90 százalékuk (9. ábra). A külföldi feldolgozóipari müködőtőkét befogadó vagy az újraiparosodó megyékben alig jegyeznek be szabadalmakat, ami jelzi az ott működö, hazai tulajdonú vállalatok innovációs stratégiáját, inkább vásárolják a technológiát (úgynevezett követő cégek). A külföldi érdekeltségü részlegek pedig elsősorban az anyavállalattal és annak háttérintézményeivel állnak kapcsolatban, gyengén kötődnek a magyar innovációs rendszerhez (Lengyel-Leydesdorff [2008]).

A gazdasági növekedés alapvető tényezőiből a fontosabbakat bemutatva, érzékelhetővé válik néhány térbeli ellentmondás. A centrumban koncentrálódik az ország munkaerö-állománya mind mennyiségi, mind minőségi szempontból, a K + F-ráfordítások és -kutatók, a tudományos fokozatúak, a külföldi müködőtőke, a vállalkozásoknak juttatott EU-támogatások, a bejegyzett szabadalmak, a felsőoktatás és a kutatók képzése (doktori iskolák) stb., ennek ellenére a fövárosi térség gazdasági növekedése 2009-től alacsony, és a munkatermelékenység is csökken. Az is ellentmondás, 
9. ábra

Az Európai Szabadalmi Hivatal által bejegyzett szabadalmak (darab/millió lakos)

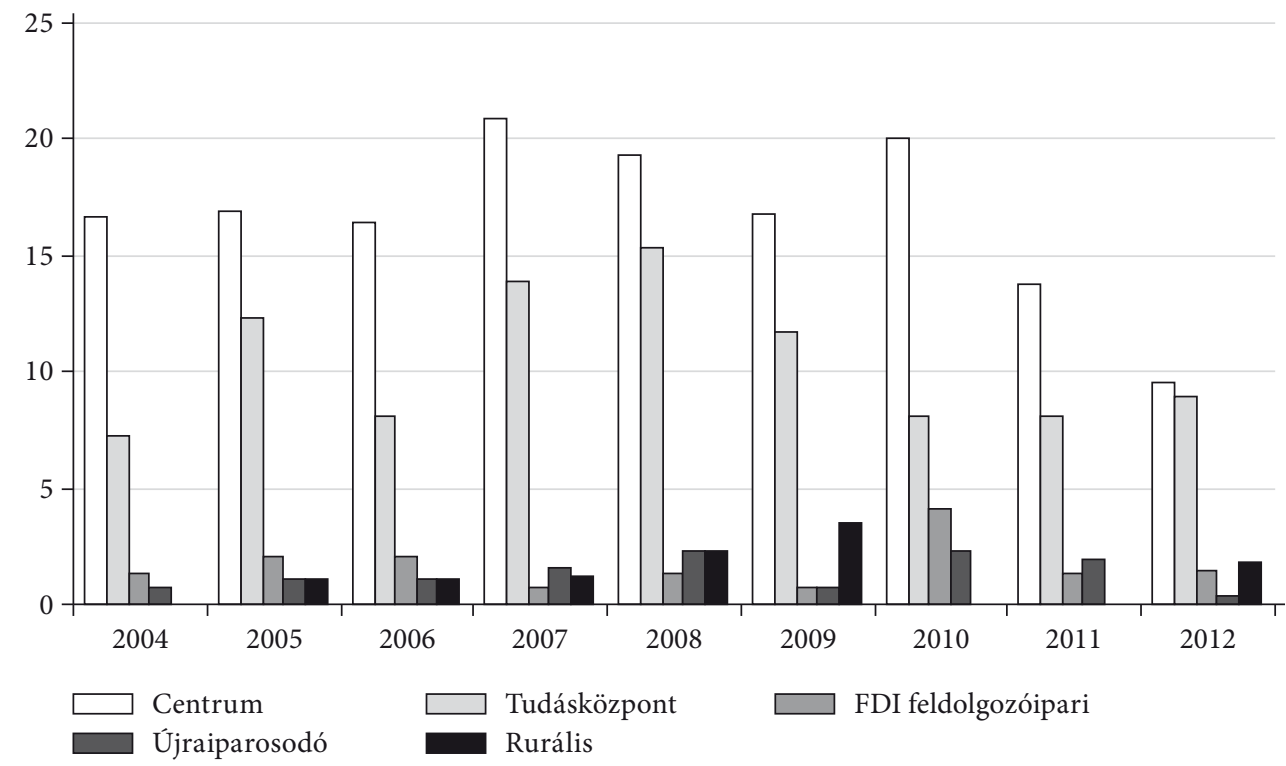

Megjegyzés: ahol egy szabadalom több feltalálója nem ugyanabban a megyében szerepel, ott az egységnyi szabadalmat a feltalálók megyéhez tartozása alapján súlyozva vettük figyelembe. Forrás: az OECD RegPat adata, amiben a European Patent Office-hoz benyújtott/bejegyzett szabadalmak szerepelnek.

hogy az ország gazdasági növekedését előidéző feldolgozóipari működőtőkét befogadó és az újraiparosodó térségekben visszaesik a munkaképes korúak száma, a $\mathrm{K}+\mathrm{F}-$ kiadások minimálisak, a diplomások és kutatók aránya alacsony, de az utánpótlásuk is nehézkes lesz a helyi felsőoktatás és doktori képzések jelentős beszükülése miatt. Ebben a két megyetípusban azonban dinamikusan nőnek a beruházások és a külföldi tőkebefektetések, amire visszavezethető a gazdasági növekedésük.

\section{Alapvető kérdések és dilemmák}

Tanulmányunkban áttekintettük az ország és a megyetípusok gazdasági növekedését és az alapvető növekedési tényezők térbeliségét. Úgy véljük, nem az a gond, hogy a tényezőknél jelentős területi egyenlőtlenségek figyelhetők meg, hanem az, hogy az ország erőforrásainak felhasználása nem hatékony. Az erőforrások koncentrálása ugyanis az agglomerációs előnyöket erősítheti, így a nemzeti szintü növekedésre pozitívan hathat. A probléma az, hogy a döntően a fővárosban és kisebb részben a nagy vidéki egyetemi központokban megfigyelt erőforrás-koncentráció nem erősíti az országos szintü növekedést.

A helyzetkép alapján számos elméleti és gazdaságpolitikai kérdés, dilemma fogalmazódott meg bennünk. A fö dilemmánk a következő: az ország gazdasági 
növekedését néhány feldolgozóipari megye generálja, ahol a külföldi müködőtőke beruházásain kívül a többi növekedési tényező erősen hiányos, miközben a jelentős forrásokat felhasználó és a hazai innovatív tényezőket (képzett munkaerő, $\mathrm{K}+\mathrm{F}$, felsőoktatás stb.) koncentráló térségek növekedése szinte stagnál. A tudásalapú gazdasági fejlődés tényezőit tömörítő főváros és az egyetemi városok stagnálása pedig a magyar gazdaság növekedését is erősen visszafogja.

\section{Elméleti felvetések és dilemmák}

a) Minek tudható be, hogy Budapest és vonzáskörzete 2007 után alig fejlödik, csökken a munkatermelékenysége, és visszafogja az ország növekedését is? Holott egyre inkább koncentrálja a minőségi termelési tényezőket (képzett munkaerő, $\mathrm{K}+\mathrm{F}$ és szabadalmak, felsőoktatás stb.), a költségvetési és EU-forrásokat, és a szakirodalom alapján azt várnánk, hogy ezen endogén tényezőket hatékonyan hasznosítva dinamikusan növekedjen, és területi multiplikátorhatásokat generáljon.

b) Milyen szerepe van az egypólusú hazai településhálózatnak a mérsékelt gazdasági növekedésben? A föváros az egyetlen olyan hazai település, ahol a növekedési tényezők kritikus tömege rendelkezésre áll (képzett munkaerő, infrastruktúra, intézmények stb.), ami agglomerációs előnyt jelenthetne a nagyvállalatok globális versenyéhez. A többi magyarországi város túl kicsi a nemzetközi versenyhez.

c) Milyen hatása figyelhető meg a közlekedésfejlesztésnek, főleg a sugárirányú autópályarendszer kiépülésének? A fajlagos szállítási költségek csökkenése az új gazdaságföldrajz szerint erőteljes térbeli koncentrálódást generál, ami már egy ideje megfigyelhető a föváros esetében, és ennek hatására kiszorulnak a vidéki vállalatok a lokális piacaikról, főleg az üzleti szolgáltatások tekintetében.

\section{Gazdaságpolitikai felvetések és dilemmák}

a) Miért nem élénkítik az európai uniós gazdaság- és vállalkozásfejlesztési források a célterületek, a kevésbé fejlett térségek gazdaságát? Több oka is lehet, a területfejlesztés felemás intézményrendszere, a centralizált fejlesztési pályázatok, a hiányzó integrált programok stb. A nemzetközi tapasztalatok alapján a projektalapú központosított fejlesztési pályázatok nem hatékonyak, helyettük integrált, helyalapú, alulról felfelé irányuló (bottom-up) gazdaságfejlesztés kellene, amit az EU is előír a 2014-2020-as költségvetési időszakra, a várostérségi multiplikátor- és kiszorító hatások előzetes elemzése alapján.

b) Milyen hosszabb távú hatása lehet annak, hogy a külföldröl irányított vállalati részlegeket, iparágakat befogadó térségek élénkítik a magyar gazdaságot? Ezekben a térségekben hiányoznak az innovatív, tartós növekedési tényezők (kutatók, $\mathrm{K}+\mathrm{F}$, szabadalmak, diplomások stb.), és egy-egy kapacitásnövelő beruházástól csak átmeneti növekedés várható.

c) Miért visszafogott a főváros térségének és a nagy vidéki egyetemeket müködtető, tudásalapú megyéknek a gazdasági növekedése? Amíg a feldolgozóiparra van Irinyi-terv, 
addig az „ipartalanodó” főváros és a vidéki egyetemi várostérségek tudás/szolgáltatás alapú fejlesztésére nincs. Az adatok alapján nagyon eltérő gazdasági lehetőségü megyetípusok vannak, amelyek fejlődésének támogatására eltérő országos programok kellenek, orientálva az alulról szerveződő és helyben koordinált kezdeményezéseket.

A dilemmák és kérdések még hosszan sorolhatók, amelyek tisztázásához alapos vizsgálatokra és széles körű szakmai vitákra van szükség. Úgy véljük, hogy az ország gazdasági növekedése a lehetőségekhez képest továbbra is visszafogott és sérülékeny marad mindaddig, amíg a mértékadó közgazdasági elemzők és a gazdaságpolitika alakítói nem veszik figyelembe a magyar gazdaság térbeli müködésének sajátosságait és az e sajátosságokkal összefüggö, régióspecifikus szakpolitikai intézkedések szükségességét.

\section{Hivatkozások}

ABReu, M. [2014]: Neoclassical regional growth models. Megjelent: Fischer-Nijkamp (szerk.) [2014] 169-191. o. https://doi.org/10.1007/978-3-642-23430-9_12.

ACs, Z.-SANDERs, M. [2014]: Endogenous growth theory and regional extensions. Megjelent: Fischer-Nijkamp (szerk.) [2014] 193-211. o. https://doi.org/10.1007/978-3-642-23430-9_13. Bod PÉTer Á́ Kоs [2016]: A magyar gazdaság növekedési képességeiről. Magyar Tudomány, 177. évf. 8. sz. 913-921. o.

CAPEllo, R. [2015]: Regional economics. 2. kiadás, Routledge, London-New York.

Capello, R.-Nijkamp, P. (szerk.) [2009]: Handbook of regional growth and development theories. Edward Elgar, Cheltenham.

Chikán Attila-Czakó Erzsébet (szerk.) [2009]: Versenyben a világgal. Vállalataink versenyképessége az új évezred küszöbén. Akadémiai Kiadó, Budapest.

Cochrane, W.-Poot, J. [2014]: Demand-driven theories and models of regional growth. Megjelent: Fischer-Nijkamp (szerk.) [2014] 259-276. o. https://doi.org/10.1007/978-3-64223430-9_15.

Csaba LÁszló [2014]: Európai közgazdaságtan. Akadémiai Kiadó, Budapest.

Dusek TAMÁs-Kiss JÁnos [2008]: A regionális GDP értelmezésének és használatának problémái. Területi Statisztika, 48. évf. 3. sz. 264-280. o.

Dusek Tamás-Kotosz Balázs [2016]: Területi statisztika. Akadémiai Kiadó, Budapest.

Elekes Zoltán [2016]: A regionális növekedés új tényezői az evolúciós gazdaságföldrajzi kutatásokban. Közgazdasági Szemle, 63. évf. 3. sz. 307-329. o. https://doi.org/10.18414/ ksz.2016.3.307.

ENYEDI GYÖRGY [2012]: Városi világ. Akadémiai Kiadó, Budapest.

ERDős Tiвor [2006]: Növekedéspotenciál és gazdaságpolitika. Akadémiai Kiadó, Budapest. ERDős Tiвor [2017]: Egy kis növekedéselmélet - másképpen. Közgazdasági Szemle, 64. évf. 5. sz. 528-545. o. http://dx.doi.org/10.18414/KSZ.2017.5.528.

Farkas BeÁta [2017]: Piacgazdaságok az Európai Unióban. Akadémiai Kiadó, Budapest. Fischer, M.-Nijkamp, P. (szerk.) [2014]: Handbook of regional science. Springer Reference, Heidelberg, https://doi.org/10.1007/978-3-642-23430-9.

GÁL Zoltán-SAss MAGdolNA-JuHÁsz BÁLInt [2016]: A külföldi közvetlentőke-befektetések és a válság hatása a fogadó gazdaságra. A visegrádi országok egyes szolgáltató ágazatainak vizsgálata. Külgazdaság, 60. évf. 7-8. sz. 51-80. o. 
Halmai PÉTer [2014]: Krízis és növekedés az Európai Unióban: Európai modell, strukturális reformok. Akadémiai Kiadó, Budapest.

Halmai PÉter [2018]: Az európai növekedési modell kifulladása. Közgazdasági Szemle, 65. évf. 2. sz. 122-160. o. https://doi.org/10.18414/ksz.2018.2.122.

Halpern László-Oblath Gábor [2014]: A gazdasági stagnálás „színe” és fonákja. Mivel jár együtt az exporttöbblet és az adósságcsökkenés? Közgazdasági Szemle, 61. évf. 7-8. sz. 757-800. o.

Komlósi Éva-Szerb LÁszló-Ács J. Zoltán-Ortega-Argilés, R. [2014]: A vállalkozási tevékenység regionális különbségei Magyarországon a regionális vállalkozási és fejlődési index alapján. Közgazdasági Szemle, 61. évf. 3. sz. 233-261. o.

KóNYA IstváN [2011]: Növekedés és felzárkózás Magyarországon, 1995-2009. Közgazdasági Szemle, 58. évf. 5. sz. 393-411. o.

KóNYA IsTVÁn [2017]: A magyar gazdasági növekedésről - egy régimódi megközelítés. Közgazdasági Szemle, 64. évf. 9. sz. 915-929. o. http://dx.doi.org/10.18414/Ksz.2017.9.915.

Kornai János [2016]: Még egyszer a „rendszerparadigmáról”. Tisztázás és kiegészítések a posztszocialista régió tapasztalatainak fényében. Közgazdasági Szemle, 63. évf. 10. sz. 1074-1119. o.

KoRnAI JÁNOs [2017]: Látlelet: Tanulmányok a magyar állapotokról. HVG Kiadó Zrt., Budapest. KPMG [2017]: A magyarországi európai uniós források felhasználásának és hatásainak elemzése a 2007-2013-as programozási időszak vonatkozásában. KPMG Tanácsadó Kft., Budapest, https://www.palyazat.gov.hu/magyarorszagi_europai_unios_forrasok_elemzese.

Krugman, P. [2003]: Földrajz és kereskedelem. Nemzeti Tankönyvkiadó, Budapest.

KSH [2017]: A Magyarországon működő külföldi irányítású leányvállalatok tevékenysége a 2015. évi végleges és a 2016. évi előzetes adatok alapján. KSH, Budapest.

Lengyel BAlázs-LeydesdorfF, L. [2008]: A magyar gazdaság tudásalapú szerveződésének mérése. Közgazdasági Szemle, 55. évf. 6. sz. 522-547. o.

Lengyel Balázs-Szanyi Miklós [2011]: Agglomerációs előnyök és regionális növekedés felzárkózó régiókban - a magyar átmenet esete. Közgazdasági Szemle, 58. évf. 10. sz. 858-876. o.

Lengyel Imre [2010]: Regionális gazdaságfejlesztés. Akadémiai Kiadó, Budapest.

Lengyel ImRe [2017]: Competitive and uncompetitive regions in transition economies: The case of the Visegrad post-socialist countries. Megjelent: Huggins, R.-Thompson, P. (szerk.): Handbook of Regions and Competitiveness: Contemporary Theories and Perspectives on Economic Development. Edward Elgar, Cheltenham, 398-415. o.

Lengyel ImRe-Kotosz Balázs [2018]: Utolérés és/vagy távolságtartó követés? A visegrádi országok térségeinek felzárkózásáról. Tér és Társadalom, 32. évf. 1. sz. 5-26. o. https://doi. org/10.17649/tet.32.1.2910.

Lengyel ImRe-Szakálné Kanó Iza bella-Vas Zsófia-Lengyel Balázs [2016]: Az újraiparosodás térbeli kérdőjelei Magyarországon. Közgazdasági Szemle, 63. évf. 6. sz. 615-646. o. http://dx.doi.org/10.18414/KSZ.2016.6.615.

Lux GÁвоR [2017]: Újraiparosodás Közép-Európában. Dialóg Campus, Budapest-Pécs.

Maier, G.-Trippl, M. [2009]: Location/allocation of regional growth. Megjelent: Capello, R.-Nijkamp, P. (szerk.) [2009] 53-65. o.

Mellár Tamás [2001]: Mikor éri el a magyar gazdaság fejlettsége az Európai Unió átlagát? Közgazdasági Szemle, 48. évf. 12. sz. 995-1008. o.

MinÁLYi PÉTER [2011]: A gazdasági növekedés gyorsításának esélyei Magyarországon 2030-ig. Competitio, 10. évf. 2. sz. 5-26. o. 
Muraközy LÁszLó [2008]: Magyarország felemelkedése és hanyatlása. Közgazdasági Szemle, 55. évf. 2. sz. 149-168. o.

Palánkai Tibor-Miklós Gábor [2014]: Magyarország integrációs profilja. Az európai integráció negyedszázados és a magyar EU-tagság tízéves mérlege. Közgazdasági Szemle, 61. évf. 4. sz. 452-485. o.

PÁlné Kovács Ilona (szerk.) [2016]: A magyar decentralizáció kudarca nyomában. Dialóg Campus Kiadó, Budapest-Pécs.

Rechnitzer János-Smahó Melinda [2011]: Területi politika. Akadémiai Kiadó, Budapest. Szerb LÁszló-Komlósi Éva-VArga AtTila [2017]: Gyors növekedésű vállalatok Magyarországon. Az innovatív, a rejtélyes és a virtuális gazellák. Közgazdasági Szemle, 64. évf. 5. sz. 476-506. o. https://doi.org/10.18414/ksz.2017.5.476.

TöröK ÁdÁm-Borsi Balázs-Telcs András [2005]: Competitiveness in Research and Development: Comparisons and performance. Edward Elgar Publishing, Cheltenham.

TóтH GÉZA [2014]: Az agglomerációk, településegyüttesek lehatárolásának eredményei. Területi Statisztika, 54. évf. 3. sz. 289-300. o. https://doi.org/10.15196/ts560101.

Valentiny Ákos [2002]: Gazdasági növekedés, felzárkózás és költségvetési politika. Közgazdasági Szemle, 49. évf. 1. sz. 1-23. o.

Varga Attila [2009]: Térszerkezet és gazdasági növekedés. Akadémiai Kiadó, Budapest. VARGA Attila [2016]: Regionális fejlesztéspolitikai hatáselemzés. Akadémiai Kiadó, Budapest. 